See discussions, stats, and author profiles for this publication at: https://www.researchgate.net/publication/308878231

\title{
Unraveling North-African riverine and eolian contributions to central Mediterranean sediments during Holocene sapropel S1 formation
}

Article in Quaternary Science Reviews · November 2016

DOI: 10.1016/j.quascirev.2016.09.029

\section{CITATIONS}

5 authors, including:

ค2 Jiawang $W u$

2. Tongji University

13 PUBLICATIONS 67 CITATIONS

SEE PROFILE

Katharina Pahnke

Institute for Chemistry and Biology of the Marine Environment (ICBM)

92 PUBLICATIONS 2,212 CITATIONS

SEE PROFILE
382

Philipp Böning

Carl von Ossietzky Universität Oldenburg

65 PUBLICATIONS 1,105 CITATIONS

SEE PROFILE

Kazuyo Tachikawa

Centre Européen de Recherche et d'Enseignement des Géosciences de l'Environn... 131 PUBLICATIONS 3,805 CITATIONS

SEE PROFILE

Some of the authors of this publication are also working on these related projects:

Project Long term climate cycles in the wet tropics View project

Project Weathering and alteration of Eocene-Oligocene basalts at the South China Sea rifted margin View project 


\title{
Unraveling North-African riverine and eolian contributions to central Mediterranean sediments during Holocene sapropel S1 formation
}

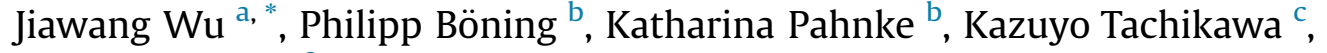 \\ Gert J. de Lange ${ }^{a}$ \\ a Department of Earth Sciences-Geochemistry, Faculty of Geosciences, Utrecht University, Princetonplein 9, 3584 CC Utrecht, The Netherlands \\ ${ }^{\mathrm{b}}$ Max Planck Research Group for Marine Isotope Geochemistry, Institute for Chemistry and Biology of the Marine Environment (ICBM), University of \\ Oldenburg, Carl-von-Ossietzky-Strasse 9-11, 26129 Oldenburg, Germany \\ ${ }^{c}$ CEREGE, Aix-Marseille Université, CNRS, IRD, Collège de France, CEREGE UM34, 13545 Aix en Provence, France
}

\section{A R T I C L E I N F O}

\section{Article history:}

Received 28 May 2016

Received in revised form

24 September 2016

Accepted 27 September 2016

\section{Keywords:}

Sapropel S1

$\mathrm{Sr}$ isotopes

$\mathrm{Nd}$ isotopes

Elemental geochemistry

Provenance

Libya

North Africa

\begin{abstract}
A B S T R A C T
Hydroclimate variability has exerted a fundamental control on the alternating deposition of organic-lean marl and organic-rich sapropel sediments in the eastern Mediterranean Sea (EMS). However, the exact mechanisms regarding the freshwater sources and related changes are still debated. Here, Sr and Nd isotopes and high-resolution elemental data are used to constrain different riverine and eolian supplies to the central Mediterranean over the past $9.8 \mathrm{ka}$. The detrital sediments in core CP10BC, taken at the margin of the Libyan shelf in the southwestern Ionian Sea, can be described by a three-endmember mixing system based on $\mathrm{Sr}$ and $\mathrm{Nd}$ isotopic compositions. The same systematics can also be deduced from Ti and K compositional variability. The endmembers comprise: Saharan Dust, Aegean/Nile, and Libyan Soil, representing the eolian supply from North Africa, the riverine inputs from the Aegean/Nile areas, as well as the riverine and shelf-derived fluxes from the Libyan-Tunisian margin, respectively. For the sapropel S1 period in particular, we find important detrital supplies from fossil river/wadi systems along the Libyan-Tunisian margin, activated by intensified African monsoon precipitation. Combining the temporal profiles with the consistent variability observed in the ${ }^{87} \mathrm{Sr} /{ }^{86} \mathrm{Sr}-1000 / \mathrm{Sr}$ diagram, such Libyan contribution has been most prominent during the uppermost period of sapropel S1 in core CP10BC. This observation is in agreement with hydroclimate reconstructions of northwestern Libya. Comparison of the $\mathrm{Sr}-\mathrm{Nd}$ isotope data between core $\mathrm{CP} 10 \mathrm{BC}$ and four cores taken along a west-east transect throughout the EMS shows that this detrital supply originated mainly from western Libya/Tunisia, and was transported as far eastward as $\sim 25^{\circ} \mathrm{E}$ while being diluted by an increasing Nile contribution.
\end{abstract}

() 2016 Elsevier Ltd. All rights reserved.

\section{Introduction}

The Mediterranean lies at the interface between the European temperate and African tropical zones. In addition, its semi-enclosed basin setting makes it particularly sensitive to changes in the hydrological cycle (Tzedakis, 2007; Magny et al., 2013; Rohling et al., 2015). This sensitivity is best witnessed by the rhythmic occurrence of sapropels, organic-rich sedimentary units deposited in the eastern Mediterranean Sea (EMS) at an astronomically determined cyclicity (Rossignol-Strick et al., 1982; Hilgen, 1991; Tuenter et al., 2003). The knowledge of sapropel formation mechanisms mostly

\footnotetext{
* Corresponding author.

E-mail address: j.w.wu@uu.nl (J.Wu).
}

relies on the last, Holocene, sapropel S1 (Rohling, 1994; Rohling et al., 2015; and references therein), because it is more easily accessible and also is the only sapropel within the range of precise radiocarbon dating. Warm and humid conditions between $\sim 10.8$ and $6.1 \mathrm{ka}$ cal. BP (hereafter referred to as "ka") have caused a pronounced density stratification of the water column and/or high primary productivity in the surface waters, ultimately resulting in deepwater stagnation and the basin-wide S1-formation in the EMS (e.g. Emeis et al., 2000; Mercone et al., 2000; Slomp et al., 2004; De Lange et al., 2008; Grimm et al., 2015; Tachikawa et al., 2015; Van Helmond et al., 2015). Enhanced freshwater influx at sapropel times has been demonstrated through $\delta^{18} \mathrm{O}$ of planktonic foraminifera (e.g. Fontugne et al., 1994; Kallel et al., 1997; Emeis et al., 2000, 2003; Rohling et al., 2002, 2004; Hennekam et al., 2014; Toucanne et al., 2015) and of cave speleothems (e.g. Bar- 
Matthews et al., 2000, 2003; Bard et al., 2002; Zanchetta et al., 2007; Spötl et al., 2010; Zhornyak et al., 2011). Although the general principles are clear, the exact mechanisms with regard to freshwater sources and associated hydroclimate changes in the circum-Mediterranean remain highly debated.

Pioneering studies have proposed increased precipitation around the Northern Borderlands of the Eastern Mediterranean (NBEM) concurrent with sapropel depositions (Rossignol-Strick, 1987; Rohling and Hilgen, 1991). This increase is corroborated by speleothem $\delta^{18} \mathrm{O}$ data from the NBEM (e.g. Zanchetta et al., 2007; Spötl et al., 2010; Zhornyak et al., 2011) and by their correspondence with the records of Soreq Cave (Bar-Matthews et al., 2000, 2003). Marine records from the eastern and central Mediterranean also confirm that increased rainfall was widespread over the NBEM during sapropel formation (e.g. Kallel et al., 1997; Emeis et al., 2000; Toucanne et al., 2015; Filippidi et al., 2016). Being seasonally specified, palynological studies demonstrate that enhanced winter precipitation was responsible for the NBEM wet conditions at times of sapropel deposition (e.g. S1: Kotthoff et al., 2008; Peyron et al., 2011; S5: Milner et al., 2012). Summer rainfall was thought to have been increased too, but this is questioned by Tzedakis (2007). Recent work has revealed north-south contrasts of precipitation seasonality in the Holocene central Mediterranean, which can reconcile the discrepancies from various proxies (e.g. Magny et al., 2011; Peyron et al., 2011, 2013; Giraudi et al., 2013; Goudeau et al., 2014, 2015). The evidence suggests that, there were also increases in 1) winter precipitation in the NBEM and 2) summer and winter precipitation in the southern EMS borderlands during S1 period, in addition to the enhanced Nile discharge (see review by Magny et al., 2013). Possible impacts of the Black Sea overflow and meltwater runoff of European ice-sheets during sapropel deposition have been excluded (Sperling et al., 2003).

Sapropels occurred at times of Northern Hemisphere insolation maxima related to the orbital cycle of precession, when the African monsoon was intensified (Rossignol-Strick et al., 1982; RossignolStrick, 1987; Hilgen, 1991; Tuenter et al., 2003). Even though the African monsoon precipitation did not directly extend to the EMS, the monsoon-fuelled Nile discharge is recognized as a key freshwater source for sapropel formation. This has been explicitly illustrated by the temporal coincidence between the S1 deposition and Nile discharge (e.g. Rossignol-Strick et al., 1982; Mercone et al., 2000; De Lange et al., 2008; Revel et al., 2010; Box et al., 2011; Hennekam et al., 2014). Apart from the Nile flooding, intensification of African monsoon precipitation had a profound and more widespread influence on the EMS during sapropel times.

Archaeological surveys suggest human occupation and dispersal over the Libyan-Saharan desert along the interlinked river-lakewetland systems during the African Humid Period (AHP; 11-5 ka) (e.g. Mandel and Simmons, 2001; Drake et al., 2011; Lézine et al., 2011; Manning and Timpson, 2014). Based on planktonic foraminiferal $\delta^{18} \mathrm{O}$ data, Rohling et al. $(2002,2004)$ suggested that the summer monsoon penetrated northward beyond the central Saharan drainage basin at $\sim 21^{\circ} \mathrm{N}$ during sapropel S5 deposition. As a consequence, activated fossil river/wadi systems along the wider North-African margin that are now buried beneath sand dunes could have debouched into the EMS. Major paleo-river systems have been revealed via satellite imagery (Paillou et al., 2009, 2012) and paleohydrological modeling (Coulthard et al., 2013). Influence of runoff from the central Saharan mountains towards the Gulf of Sirte during sapropel S5 period is also shown in Nd isotopes of planktonic foraminifera (Osborne et al., 2008, 2010). This freshwater route into the EMS may have rivaled the Nile runoff in magnitude (Scrivner et al., 2004), favored human migrations out of Africa (Osborne et al., 2008; Coulthard et al., 2013), and possibly operated for a majority of Quaternary sapropels (e.g. S1: Fontugne et al., 1994; S6: Emeis et al., 2003). Although the origin of Nd recorded in planktonic foraminifera is still controversial (see review by Tachikawa et al., 2014), this scenario is supported by dust variations over the past $3 \mathrm{Ma}$ in combination with other Saharan data (Larrasoaña et al., 2003, 2013). However, so far there is no marine evidence whether the fossil river/wadi route was active during sapropel S1 time. In this paper we focus on such riverine contribution by analyzing the detrital component of EMS sediments.

It has been suggested that clay minerals of surface sediments over most of the EMS can be described by a simple twoendmember mixing model, with Saharan dust and Nile sediment as the dominant sources (e.g. Venkatarathnam and Ryan, 1971; Ehrmann et al., 2007a; Hamann et al., 2009). From a long-term perspective, various records of clay minerals and major elements reflect consistent sapropel-related alternations between riverine and eolian endmembers (e.g. Wehausen and Brumsack, 1999, 2000; Foucault and Mélière, 2000; Lourens et al., 2001; Zhao et al., 2012, 2016). However, only a few high-resolution studies on the detrital composition of marine sediments exist, and most of these are focused on the Nile-dominated region (e.g. Hamann et al., 2009; Revel et al., 2010, 2015; Box et al., 2011; Hennekam et al., 2014, 2015). Very little is known about the supplies of numerous small rivers from other sources through time. In particular, potential riverine supplies from the wider North-African margin may have been underestimated, or even neglected.

Paired $\mathrm{Sr}$ and $\mathrm{Nd}$ isotopes have shown to be a powerful tool for provenance studies. Their isotopic ratios in lithogenic sediments have characteristic fingerprints of source rocks, with little effect of transport processes and diagenesis (e.g. Freydier et al., 2001; Weldeab et al., 2002a, 2002b; Revel et al., 2010, 2015; RodrigoGámiz et al., 2015; Castañeda et al., 2016). In addition to radiogenic isotopic tracers, elemental geochemistry of marine sediments can be used to track changes in detrital inputs (e.g. Wehausen and Brumsack, 1999, 2000; Bout-Roumazeilles et al., 2013; Wu et al., 2013; Klaver et al., 2015). Lower Ti/Al and Zr/Al values and higher K/ Al ratios during humid sapropel periods are generally interpreted as a sign of reduced eolian and enhanced riverine fluxes, and vice versa for more arid conditions (see review by Martinez-Ruiz et al., 2015). Here, combining Sr and Nd isotopes with major elements, we present a high-resolution record of the origin of detrital sediments over the past $9.8 \mathrm{ka}$ using a well-dated boxcore. Core CP10BC was strategically retrieved from the southwestern Ionian Sea, at the margin of the Libyan shelf (Fig. 1). The sediment provenance for this area is thought to be influenced by Saharan dust and riverine sources from northern and southern EMS borderlands, with a presumably limited Nile contribution. Therefore, this core represents an excellent location to understand the nature and importance of rivers flowing north out of the Sahara during sapropel S1 time. Furthermore, by comparing the Sr-Nd isotope data of core CP10BC with four cores taken along a west-east transect throughout the EMS, a detailed evaluation can be made of the potential distribution of detrital material.

\section{Recent regional settings}

\subsection{Hydroclimate}

The Mediterranean climate is characterized by marked seasonality in rainfall (Magny et al., 2013; Rohling et al., 2015 and references therein; Castañeda et al., 2016). General features are summarized as follows (Fig. 1a). During summer, the Mediterranean is dominated by the subtropical high-pressure belt resulting in dry and hot conditions, especially in the southeastern sector (Lolis et al., 2002). In winter, the high-pressure belt migrates southward and the Mediterranean comes under the control of the 


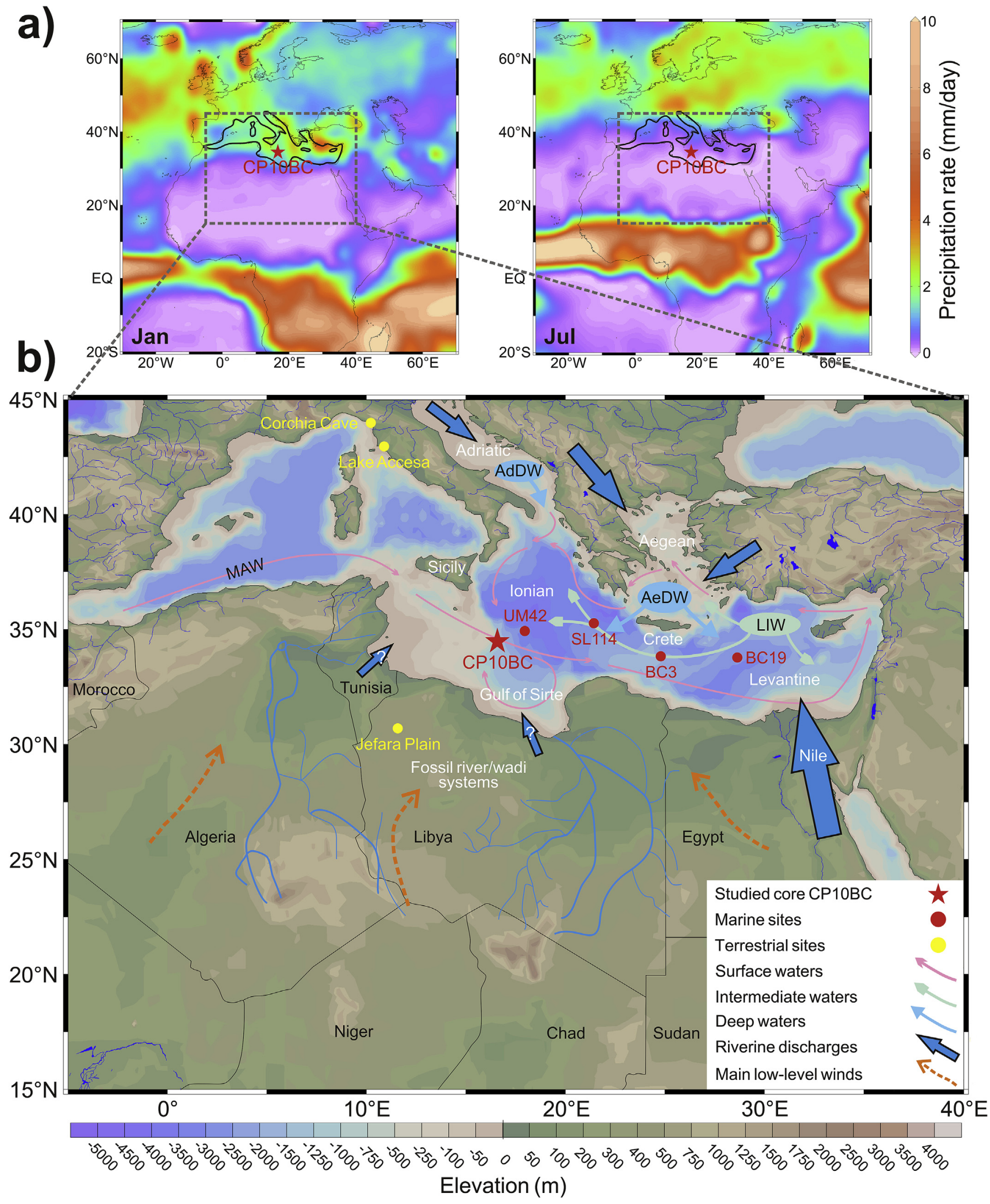

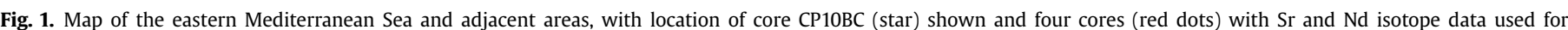

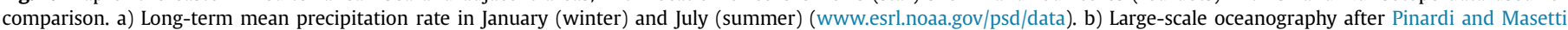

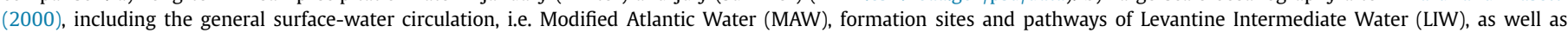

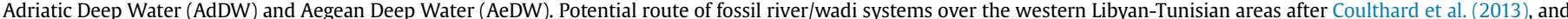

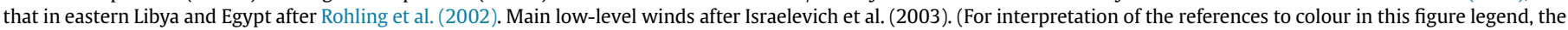
reader is referred to the web version of this article.) 
westerlies, which drive an eastward transport of Atlantic depressions, bringing enhanced precipitation over the northern borderlands (i.e. NBEM) (Rohling and Hilgen, 1991; Lolis et al., 2002).

\subsection{Water masses and circulation}

The climate strongly influences the physical parameters of the surface waters, which play a central role in controlling the thermohaline circulation in the EMS (Pinardi and Masetti, 2000; Pinardi et al., 2015; and references therein) (Fig. 1b). Inflowing surface waters occupying the upper $200 \mathrm{~m}$ depth, called Modified Atlantic Water (MAW), flow eastward along the North-African coast. The MAW splits into two branches; one turns southward into a broad anticyclonic pattern in the Gulf of Sirte, while the other continues in an easterly direction with increasing salinity, following a largescale counter-clockwise pathway (Pinardi and Masetti, 2000; Béranger et al., 2005; Pinardi et al., 2015). The eastern-most MAW cools in winter and forms the Levantine Intermediate Water (LIW). The LIW flows westward at 200-600 m depth as the salty outflow waters, and also contributes to the formation of Adriatic Deep Water (AdDW) and Aegean Deep Water (AeDW) found below 800 m (Roether et al., 1996; Pinardi and Masetti, 2000; Pinardi et al., 2015).

\subsection{Detrital sediment provenance}

The amount and composition of riverine supply depends on the extent of catchment areas, exposed rocks, and weathering conditions (Fig. 1b). The Nile is the longest river on Earth, comprising two different systems: 1) the White Nile and 2) the Blue Nile and Atbara (Williams et al., 2000). The latter drains the Ethiopian highlands that predominantly consist of continental flood basalts of Tertiary age, affected by the East African monsoon in summer, resulting in the annual Nile flood (Hennekam et al., 2014; Castañeda et al., 2016). At present the Sudd swamps in Sudan filter out most of the suspension load of the White Nile, the Blue Nile and Atbara account for $>50 \%$ of the water flow and $>95 \%$ of the sediment load ( $230 \mathrm{Mt} / \mathrm{yr}$ ) (Foucault and Stanley, 1989; Williams et al., 2000; Padoan et al., 2011). The coarser fraction of Nile sediments is mostly deposited on the delta, and the finer fraction is transported in a counter-clockwise gyre within the Levantine Basin. Prior to the completion of the Aswan Dan in 1965, only a small fraction of modern Nile-derived particulates is thought to be transported to areas west of Crete (Krom et al., 1999a; Weldeab et al., 2002a).

Numerous small rivers in the NBEM are major contributors to detrital deposition in the Ionian Sea (Fig. 1b). The Turkish rivers $(\sim 17 \mathrm{Mt} / \mathrm{yr})$, southeastern European rivers ( $30 \mathrm{Mt} / \mathrm{yr})$, and the Po ( $17 \mathrm{Mt} / \mathrm{yr}$ ) yield substantial sediment loads into the Aegean and Adriatic Sea (after Bout-Roumazeilles et al., 2013). Part of this may subsequently be transported to the Ionian Sea by oceanic currents (Venkatarathnam and Ryan, 1971; Ehrmann et al., 2007a; Goudeau et al., 2013). This river-borne material reflects the weathering and erosion products of basalts and ultramafic rocks in relation to the lithology of the catchments (Weldeab et al., 2002a; Klaver et al., 2015).

Present-day riverine contribution to the Ionian Sea from the North-African margin is limited because of small catchments and sparse rainfall. Nevertheless, due to the regional topography and seasonal precipitation, ephemeral rivers draining northward from the central Saharan mountains may have been a considerable supplier of detrital material, especially during the humid sapropel times (Drake et al., 2011; Lézine et al., 2011; Scheuvens et al., 2013) (Fig. 1b). The river channels dissipate in the desert, but some converge forming the main river/wadi systems. The Irharhar, for instance, is associated with dry/salt lakes in Tunisia and Algeria, fed by rainfall and groundwater, flowing towards the Libyan-Tunisian coast (Paillou et al., 2009, 2012; Drake et al., 2011; Coulthard et al., 2013). Moreover, the irregularly active river/wadi systems can provoke turbid flows associated with high detrital fluxes into the Ionian Sea (Weldeab et al., 2002a; Zielhofer et al., 2008).

Saharan dust is the dominant source of the EMS detrital sediment ( 25-100 Mt/yr) (see compilations in Goudie and Middleton, 2001), notably for the Ionian Sea receiving low riverine input (Guerzoni et al., 1997; Rutten et al., 2000). Dust from the northern and eastern EMS borderlands is quantitatively negligible (Guerzoni et al., 1997; Ehrmann et al., 2007a). The source areas consist mainly of Precambrian granitoid rocks in the central Sahara, and of limestone in the North (Moreno et al., 2006). Major dust production for the EMS originates from hyperarid areas with little/no vegetation (see Scheuvens et al., 2013), including the Bodélé Depression in Chad, western Sahara, Tunisia/northern Algeria, and central Libya. The northward delivery of Saharan dust is primarily via low-level winds (Goudie and Middleton, 2001; Stuut et al., 2009; Israelevich et al., 2012), which can be related to the coupling of sea-surface temperature to atmospheric pressure over the Mediterranean Sea (Jilbert et al., 2010).

\section{Material and methods}

Core CP10BC $\left(34^{\circ} 32.7^{\prime} \mathrm{N}, 16^{\circ} 34.0^{\prime} \mathrm{E} ; 1501 \mathrm{~m}\right.$ water-depth) was collected during the RV Pelagia cruise CORTADO in 2011 (Fig. 1). This $35.5 \mathrm{~cm}$ long boxcore consists of foraminifera and pteropod marl ooze, with a distinct S1 unit. The olive-grey S1 is $\sim 10 \mathrm{~cm}$ thick at the bottom; a diffuse dark band occurs at $~ 16-24 \mathrm{~cm}$ depth, well above the visual $\mathrm{S} 1$. Normal yellowish-brown sediments are intercalated between the two layers. Two subcores were sampled so as to have enough material for all analyses. For subcore CP10BC\#1 every $0.25 \mathrm{~cm}$ were sampled resulting in a total of 142 samples, which were freeze-dried and finely ground for subsequent geochemical analyses. Subcore $\mathrm{CP} 10 \mathrm{BC} \# 3$ was sampled at intervals of $0.5 \mathrm{~cm}$ for foraminiferal radiocarbon dating.

\subsection{Age model}

The chronology of core $\mathrm{CP} 10 \mathrm{BC}$ is based on 4 Accelerator Mass Spectrometry (AMS) ${ }^{14} \mathrm{C}$ dates on planktonic foraminifers, done at the Poznan Radiocarbon Laboratory (Table 1). Approximately $15 \mathrm{mg}$ of mixed planktonic foraminifers (Globigerinoides ruber and Globigerinoides sacculifer) in the $150-600 \mu \mathrm{m}$ fractions was picked. All ${ }^{14} \mathrm{C}$ dates were converted into calendar ages using the Marine13 calibration curve (Reimer et al., 2013) implemented in the program Calib 7.0 (Stuiver et al., 2005), with no regional reservoir correction (i.e. $\Delta \mathrm{R}=0$ ) that is valid for the modern Mediterranean (Siani et al., 2000). Inventories and activities of ${ }^{210} \mathrm{~Pb}$ and ${ }^{137} \mathrm{Cs}$ were determined for 9 samples of bulk sediment (see Barsanti et al., 2011), showing that minor bioturbation affected the top $3 \mathrm{~cm}$ at most; thus the age of core-top is assessed to be the present-day.

The age model was developed by linear interpolation between these 5 tie-points, yielding a highly consistent depth-age curve, with the basal age of 9.8 ka that refers to the start of S1 here (Fig. 2). The average sedimentation rate is $3.6 \mathrm{~cm} / \mathrm{ka}$.

\subsection{Total organic carbon}

Total organic carbon (TOC) was measured on decarbonated samples following the protocol described in Van Santvoort et al. (1996). Powdered bulk sediments were decarbonated by shaking in $1 \mathrm{M} \mathrm{HCl}$ for $4 \mathrm{~h}$ firstly, then for $12 \mathrm{~h}$. Subsequently, samples were rinsed twice with deionized water, oven-dried at $80^{\circ} \mathrm{C}$, and ground. Replicate analyses of in-house standards and selected samples 
Table 1

Core $\mathrm{CP} 10 \mathrm{BC}$ radiocarbon chronology.

\begin{tabular}{|c|c|c|c|}
\hline Lab code & Depth $(\mathrm{cm})$ & ${ }^{14} \mathrm{C}$ age $\pm 2 \sigma($ yr BP $)$ & Calibrated age $\pm 2 \sigma(\mathrm{yr} \text { cal. BP })^{\mathrm{a}}$ \\
\hline Poz-55177 & $6-6.5$ & $2280 \pm 30$ & $1893 \pm 85$ \\
\hline Poz-55178 & $18.5-19$ & $5130 \pm 40$ & $5486 \pm 99$ \\
\hline Poz-55179 & $28-28.5$ & $7330 \pm 40$ & $7795 \pm 107$ \\
\hline Poz-55180 & $34-34.5$ & $8770 \pm 50$ & $9423 \pm 101$ \\
\hline
\end{tabular}

${ }^{a}$ Using Marine13 calibration curve (Reimer et al., 2013), implemented in program Calib 7.0 (Stuiver et al., 2005), with no regional offset ( $\Delta \mathrm{R}=0$ ) (Siani et al., 2000).

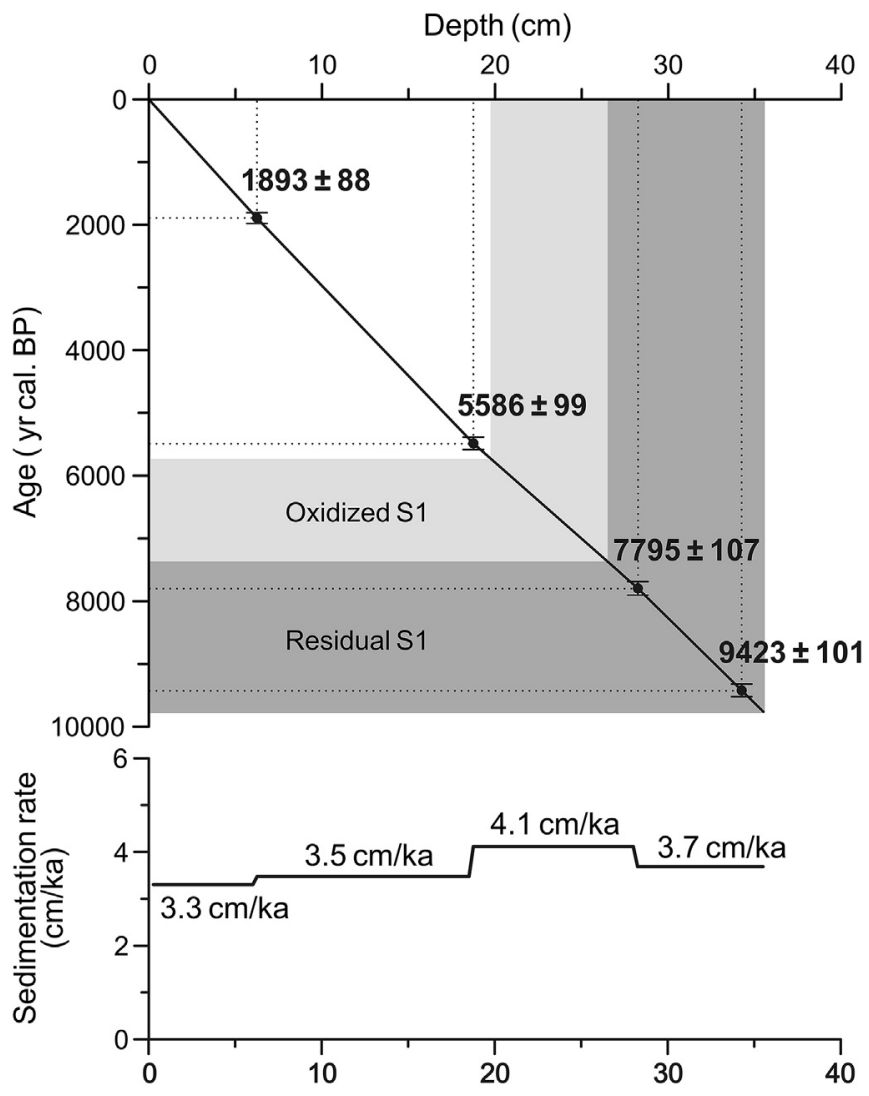

Fig. 2. Age model and inferred sedimentation rate for core $\mathrm{CP} 10 \mathrm{BC}$, with dark and light shadings showing the residual and oxidized parts of sapropel S1, respectively. The $2 \sigma$ errors are specified. Data sources refer to Table 1.

show that the relative deviations are $<3 \%$.

\subsection{Major and minor elements}

Elemental composition was analyzed by Inductively Coupled Plasma-Optical Emission Spectroscopy (ICP-OES) on a Spectro Arcos after a three-step total digestion (Reitz et al., 2006). First, $\sim 125 \mathrm{mg}$ of powdered sediments was digested in a mixture of $2.5 \mathrm{ml}$ concentrated $\mathrm{HF}$ and $2.5 \mathrm{ml}$ pre-mixed acid (3:2 concentrated $\mathrm{HClO}_{4}$ and $\mathrm{HNO}_{3}$ ), and heated at $90{ }^{\circ} \mathrm{C}$ in a gastight Teflon vessel for $12 \mathrm{~h}$. Subsequently, the solution was evaporated at $160{ }^{\circ} \mathrm{C}$ to near dryness, and then the residue was dissolved in $25 \mathrm{ml}$ of $4.5 \%$ $\mathrm{HNO}_{3}$ at $90{ }^{\circ} \mathrm{C}$ for $6 \mathrm{~h}$. For the samples with very high Mn concentrations, the procedure was applied to $\sim 30 \mathrm{mg}$ sediment with additional peroxide steps (see Reitz et al., 2006). Reported concentrations are on bulk sediment basis, expect for $\mathrm{Sr}$ content that was determined on the decarbonated fraction so as to represent the detrital phase alone (c.f. Section 3.2). Analytical uncertainties were monitored by international standard (ISE 921; Van Dijk and Houba, 2000), replicates, and blanks, showing that the relative deviations are $<5 \%$ for all targeted elements.

\subsection{Sr and Nd radiogenic isotopes}

A selection of 27 samples was processed for $\mathrm{Sr}$ and $\mathrm{Nd}$ isotopic compositions at the Institute for Chemistry and Biology of the Marine Environment (ICBM) in Oldenburg. Decarbonation (c.f. Section 3.2) and Fe-Mn oxyhydroxide leaching were done to ensure that the analyses represent the detrital component alone. To remove the authigenic Fe-Mn oxyhydroxides, decarbonated samples were leached for $2 \mathrm{~h}$ with a solution of $0.02 \mathrm{M}$ hydroxylamine hydrochloride in 25\% acetic acid. This was repeated for $6 \mathrm{~h}$ twice, followed by three times rinsing with deionized water. The remaining siliciclastic fraction was dissolved using a routine threestep total digestion (c.f. Section 3.3).

Briefly, $\mathrm{Sr}$ and rare earth elements (REE) were separated using $100 \mu \mathrm{l}$ Teflon columns filled with Eichrom TRU-Spec resin. Sr and Rb were collected in $1 \mathrm{M} \mathrm{HNO}_{3}$ and REE in $1 \mathrm{M} \mathrm{HCl}$. Subsequently, $30 \mu \mathrm{l}$ Teflon columns with Eichrom $\mathrm{Sr}$-Spec resin were used to isolate $\mathrm{Sr}$ from the $\mathrm{Sr}-\mathrm{Rb}$ cuts, via washing out $\mathrm{Rb}$ in $3 \mathrm{M} \mathrm{HNO}_{3}$ and then collecting $\mathrm{Sr}$ in Milli-Q water. Separation of Nd from other REE was performed on $250 \mu \mathrm{l}$ Teflon columns using Eichrom Ln-Spec resin and $0.25 \mathrm{M} \mathrm{HCl}$ as eluent.

Isotope measurements were done by Multi-Collector Inductively Coupled Plasma-Mass Spectrometry (MC-ICP-MS) using the Thermo Scientific Neptune Plus at the ICBM. The measured ${ }^{87} \mathrm{Sr} /{ }^{86} \mathrm{Sr}$ and ${ }^{143} \mathrm{Nd} /{ }^{144} \mathrm{Nd}$ ratios were corrected for mass fractionation by normalizing to ${ }^{86} \mathrm{Sr} /{ }^{88} \mathrm{Sr}=0.1194$ and ${ }^{146} \mathrm{Nd} /{ }^{144} \mathrm{Nd}=0.7219$ and the exponential law, and are reported relative to the standards NBS-SRM $987\left({ }^{87} \mathrm{Sr} /{ }^{86} \mathrm{Sr}=0.710248\right.$; Thirlwall, 1991) and JNdi $\left({ }^{143} \mathrm{Nd} /{ }^{144} \mathrm{Nd}=0.512115\right.$; Tanaka et al., 2000), respectively. The $2 \sigma$ external reproducibility was checked by repeated analysis of standards NBS-SRM 987 (40 ppm, $\mathrm{n}=12$ ) and JNdi (24 ppm, $\mathrm{n}=17$ ) (Table 1). The $\mathrm{Nd}$ isotopic ratio is expressed as: $\varepsilon_{\mathrm{Nd}(0)}=\left[\left({ }^{143} \mathrm{Nd} /{ }^{144} \mathrm{Nd}\right)_{\text {measured }} /\left({ }^{143} \mathrm{Nd} /{ }^{144} \mathrm{Nd}\right)_{\mathrm{CHUR}}\right.$ $-1] \times 10^{4}$, while CHUR (chondritic uniform reservoir) is 0.512638 (Jacobsen and Wasserburg, 1980). Blank levels were negligible in all cases. Krypton "gas blanks" as well as Rb and Ba levels in the measured $\mathrm{Sr}$ solutions were also negligible.

The $\mathrm{Sr}$ and $\mathrm{Nd}$ isotope data of four additional cores have been analyzed at CEREGE and are used for a west-east comparison throughout the EMS. The data of cores UM42, BC3, and BC19 have been published (Freydier et al., 2001), while the data from boxcore SL114 ( $35^{\circ} 17.2^{\prime} \mathrm{N}, 2^{\circ} 24.5^{\prime} \mathrm{E}$; 3390 m depth) obtained during the RV Logachev cruise SMILABLE in 1999, are new. The analytical procedures for these four cores are the same and were given in Freydier et al. (2001).

\section{Results}

\subsection{Sapropel geochemistry (TOC, $B a, M n)$ in core $C P 10 B C$}

Sedimentation rates are relatively high during the S1 period and relatively low for the more recent, arid interval (Fig. 2). The low TOC content in the uppermost 5 ka reflects the overall low productivity 
and oxic conditions in the EMS (Fig. 3a). In the lower part, the residual S1 is characterized by $1.2-1.7 \%$ TOC content, while the full extent of S1 is recognized by the elevated $\mathrm{Ba} / \mathrm{Al}$ zone (Fig. $3 \mathrm{~b}$ ). This difference is due to post-depositional oxidation that removed most of the TOC but not biogenic Ba from the upper-most S1 interval (De Lange et al., 1989; Van Santvoort et al., 1996). Biogenic Ba (mainly barite, refer to as "Ba") was corrected by the equation: $\mathrm{Ba}=\mathrm{Ba}_{\mathrm{blk}}-$ $\left[\mathrm{Al}_{\text {blk }} \times(\mathrm{Ba} / \mathrm{Al})_{\text {det }}\right]$, where $\mathrm{Ba}_{\mathrm{blk}}$ and $\mathrm{Al}_{\text {blk }}$ are concentrations in bulk sediments, and $(\mathrm{Ba} / \mathrm{Al})_{\operatorname{det}}$ represents the average $\mathrm{Ba} / \mathrm{Al}$ ratio of EMS detrital sediments $(0.0033 \mathrm{~g} / \mathrm{g}$ ) (Rutten and de Lange, 2002). Due to its conservative behavior, $\mathrm{Al}$ is adopted as a normalizing parameter to assess the relative enrichment/depletion of specific elements (Martinez-Ruiz et al., 2015; and references therein).

The two separated Mn-rich zones at 7.3 and 5.8 ka correspond to the upper boundary of the residual and the initial S1, respectively (Fig. 3c). It has been demonstrated that the lower Mn-peak is forming actively, whereas the upper one is related to reventilation of the water column during S1 termination (Van Santvoort et al., 1996; Reitz et al., 2006). Defined by the Ba/Al ratio reflecting initial TOC accumulation rates, and the upper $\mathrm{Mn} / \mathrm{Al}$ peak signaling the conversion from anoxic to oxic conditions, the S1 formation ended at $\sim 5.8 \mathrm{ka}$ in core CP10BC (Fig. 3). This is within the range of previous studies $(\sim 6.1 \pm 0.5 \mathrm{ka})$ (Mercone et al., 2000; De Lange et al., 2008). Note that bulk Ba associated with $\mathrm{MnO}_{\mathrm{x}}$ may be enhanced at the major Mn-peak, causing a seemingly younger S1ending age according to the Ba/Al profile (see Reitz et al., 2006). Sapropel S1 is split into S1a and S1b at $~ 8.0 \mathrm{ka}$, based on the ends of increasing trends of $\mathrm{TOC}$ and $\mathrm{Ba} / \mathrm{Al}$, as well as of decreasing (increasing) trend of ${ }^{87} \mathrm{Sr} /{ }^{86} \mathrm{Sr}\left(\varepsilon_{\mathrm{Nd}(0)}\right)$ (Figs. 3 and 4 ). This timing is close to the well-known 8.2 ka event (Rohling and Pälike, 2005).

\subsection{Detrital elements (Ti, Zr, K) in core CP10BC}

There is a strong similarity between $\mathrm{Ti} / \mathrm{Al}$ and $\mathrm{Zr} / \mathrm{Al}$ profiles obtained for the bulk sediments, showing lower values in the S1 section and higher values in the upper part of the core, with a minimum at $\sim 7.0-6.0 \mathrm{ka}$ (Fig. $4 \mathrm{~b}$ and c). By contrast, $\mathrm{K} / \mathrm{Al}$ is highest in the lower and upper parts, showing a rather broad minimum at $\sim 5.0-4.0$ ka (Fig. 4d). In the plot of Ti/Al vs. K/Al (Fig. 5a), the sapropel samples have lower $\mathrm{Ti} / \mathrm{Al}$ ratios relative to the nonsapropel samples. The S1a samples report generally higher K/Al ratios, while the S1b samples show lowest Ti/Al values and a major decrease in K/Al.

\subsection{Sr contents, and Sr-, Nd-isotopes of detrital sediments in cores CP1OBC and SL114}

After removing the carbonate, the remaining detrital Sr content in core CP10BC is relatively low ( 110-187 ppm) (Table 2; Fig. 4e). The ${ }^{87} \mathrm{Sr} /{ }^{86} \mathrm{Sr}$ ratio of the detrital fractions has a large variation (0.7146-0.7199), whereas the $\varepsilon_{\mathrm{Nd}(0)}$ values vary within a narrow range ( -12.0 to -10.8 ) (Table 2; Fig. $4 \mathrm{f}$ and $\mathrm{g}$ ). A strong negative correlation between detrital ${ }^{87} \mathrm{Sr} /{ }^{86} \mathrm{Sr}$ and $\varepsilon_{\mathrm{Nd}(0)}$ values is displayed (Figs. 4 and 6). The Sr content expressed as 1000/Sr also co-varies with ${ }^{87} \mathrm{Sr} /{ }^{86} \mathrm{Sr}\left(R^{2}=0.30\right)$ (Figs. 4 and 7$)$. The ${ }^{87} \mathrm{Sr} /{ }^{86} \mathrm{Sr}$ ratios in core SL114 are similar to those in core CP10BC, whereas during S1 the $\varepsilon_{\mathrm{Nd}(0)}$ values of SL114 are higher than for CP10BC (Table 3; Fig. 8).

The interval of $\sim 3.0-1.5 \mathrm{ka}$ is deviating in geochemical compositions (e.g. Ti/Al, K/Al, Sr contents, and ${ }^{87} \mathrm{Sr} /{ }^{86} \mathrm{Sr}$ ) (Fig. 4), which is related to dispersed tephra occurrence as identified in several samples. As tephra is not our focus here, we will disregard this interval hereafter.

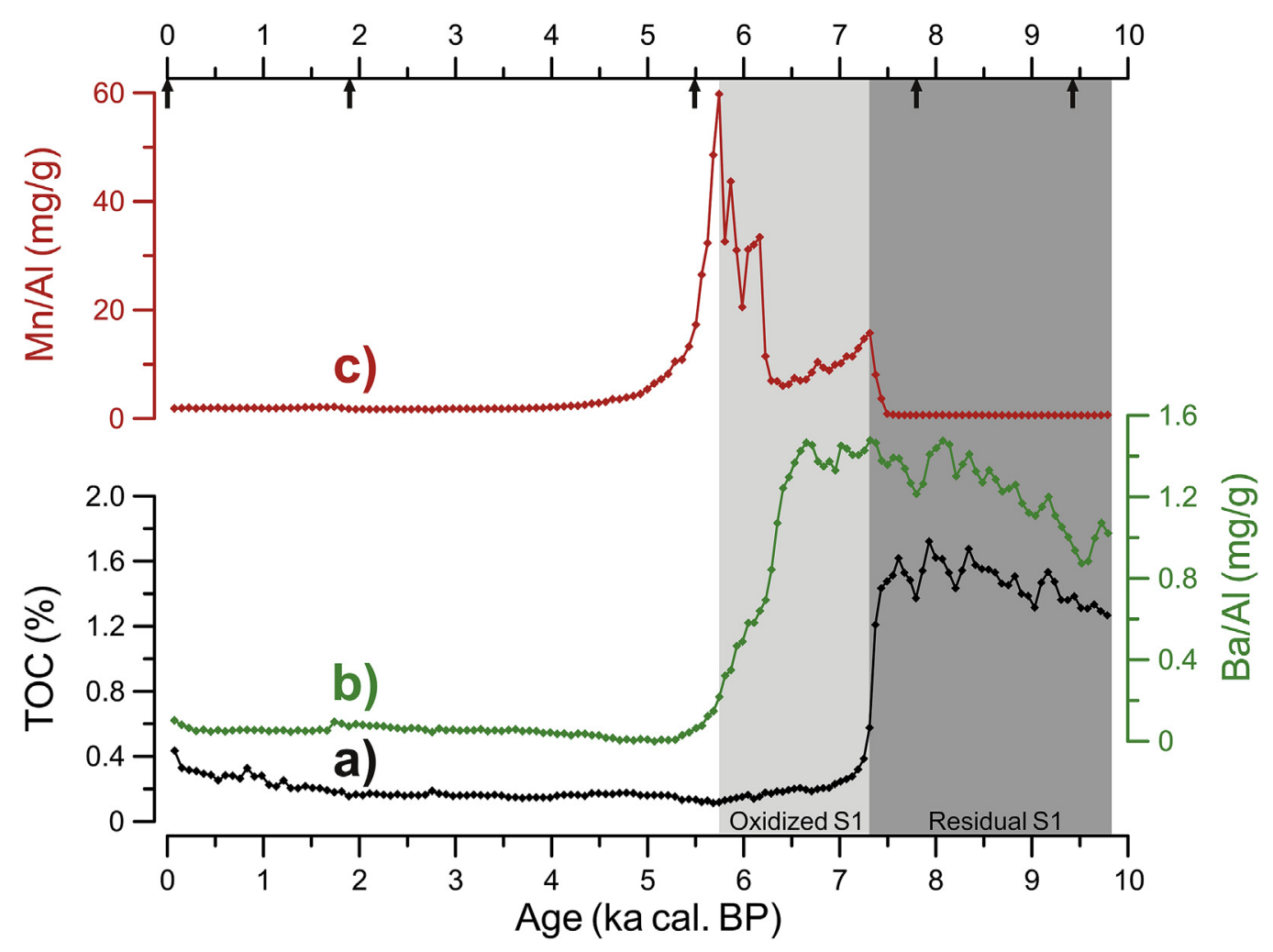

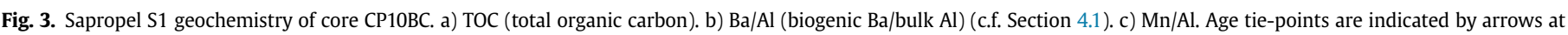
upper axis. Dark and light shadings show the residual and oxidized parts of sapropel S1, respectively. 


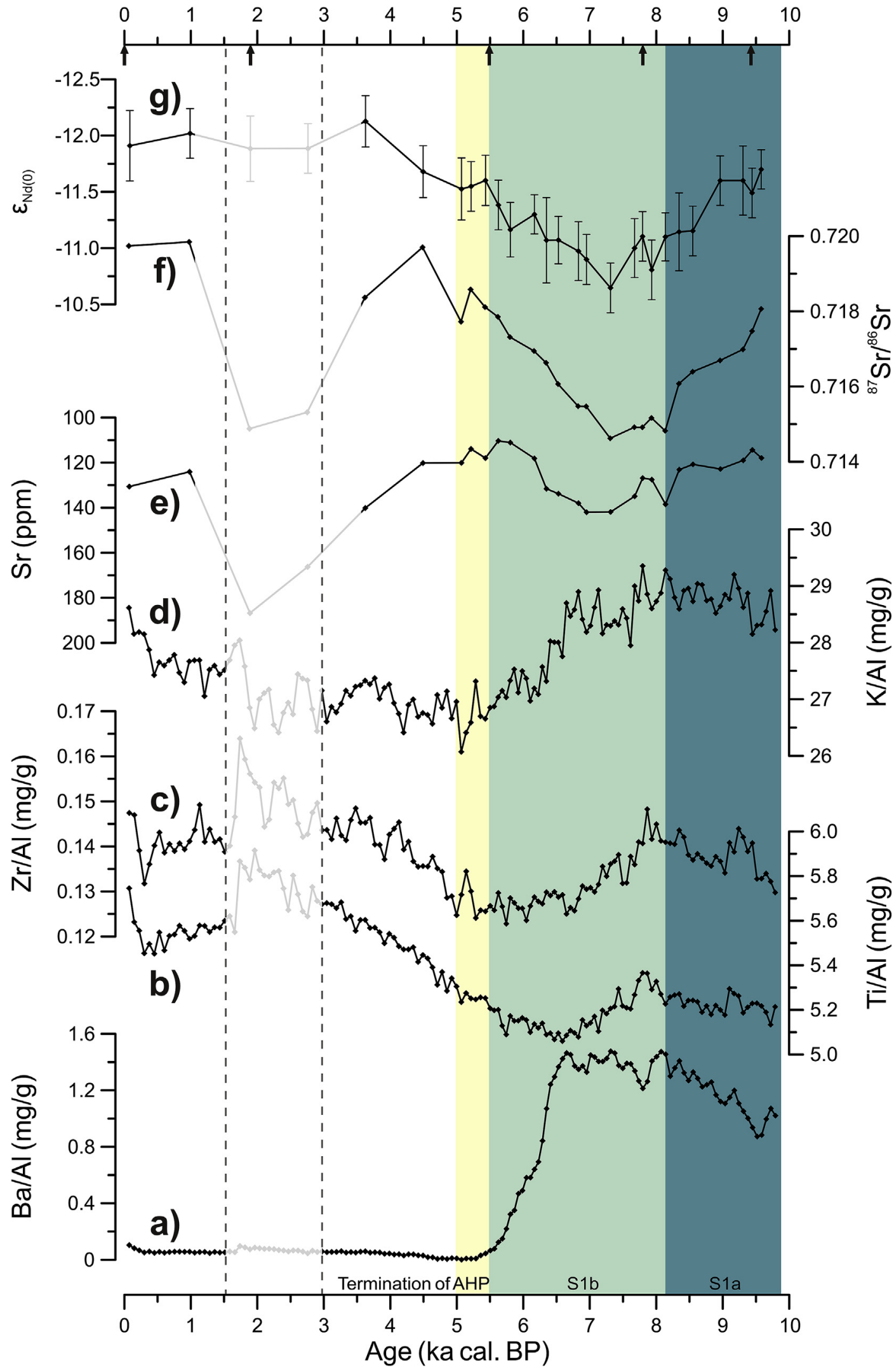

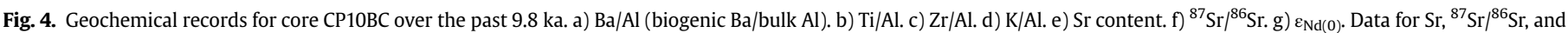

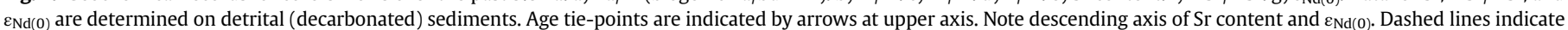
the tephra-related interval mentioned in Section 4.3, to be disregarded in this contribution. Sapropel S1a, S1b, and termination of AHP (African Humid Period) are specified. 


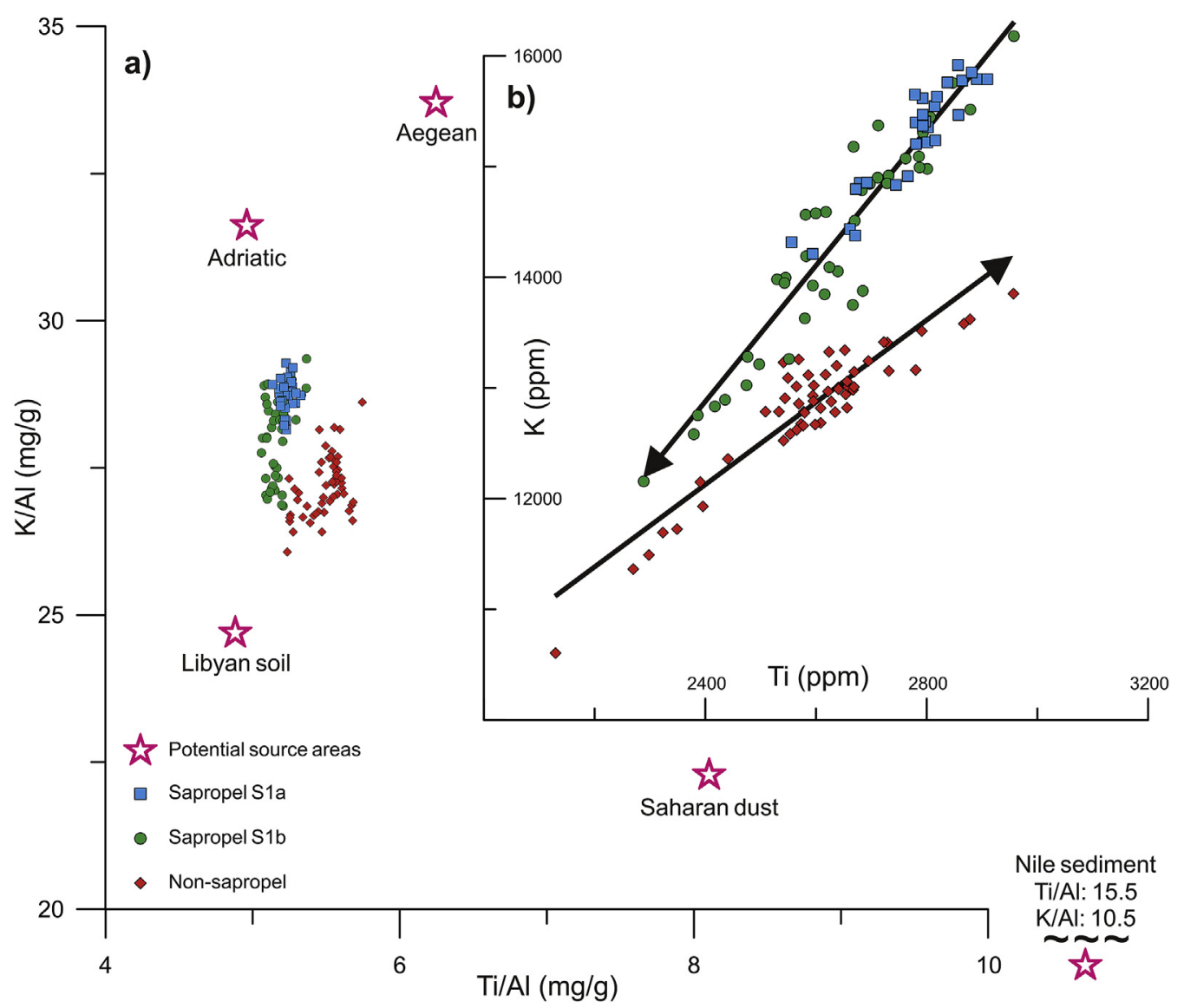

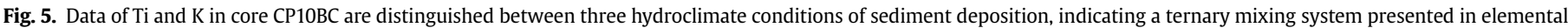

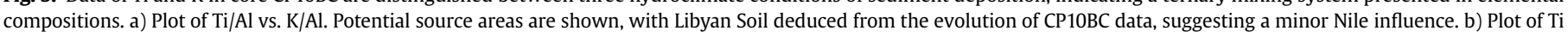

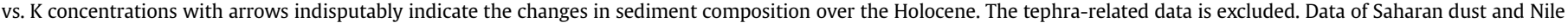
sediment after Krom et al. (1999a; 1999b); surface sediment data of Aegean (Karageorgis et al., 1998) and Adriatic (Dolenec et al., 1998) seas reported as average values.

\section{Discussion}

Characterization of detrital supplies and their attribution to different sources are prerequisites for hydroclimate reconstruction. Previous studies on modern EMS sediments have reported a clear west-east gradient in geochemical signatures, due to mixing between distinct endmembers: "young and mafic" Nile sediment is diluted towards the west by "old and felsic" Saharan dust, while riverine contributions derived from basalts and ultramafic rocks over the NBEM have also been proposed (e.g. Venkatarathnam and Ryan, 1971; Krom et al., 1999a; Weldeab et al., 2002a; Klaver et al., 2015). It has been suggested that this recent provenance pattern was also present in the Quaternary (Krom et al., 1999b; Freydier et al., 2001; Weldeab et al., 2002b; Revel et al., 2010, 2015), Pliocene (Wehausen and Brumsack, 1999, 2000; Nijenhuis and de Lange, 2000), and even pre-Pliocene (Klaver et al., 2015) sediments. The reported sources have well-defined Sr-Nd isotopic signatures (Table 4; and references therein), but the underlying datasets do not adequately cover the Ionian Sea, especially the key margin areas (see Ayache et al., 2016).

Here, we combine detrital $\mathrm{Sr}$ and $\mathrm{Nd}$ isotopic compositions with high-resolution elemental ratios ( $\mathrm{Ti} / \mathrm{Al}, \mathrm{Zr} / \mathrm{Al}$, and $\mathrm{K} / \mathrm{Al}$ ) from bulk sediments to unravel the provenance of sediments in the central Mediterranean during the Holocene. We first propose a threeendmember mixing hypothesis, which will be examined by a west-east comparison throughout the EMS, and finally reconstruct the changes in different detrital contributions with implications for hydroclimate over the circum-Mediterranean.

\subsection{A three-endmember mixing system for detrital sediments in core $C P 10 B C$}

In terms of Sr-Nd isotopic and elemental compositions, a simple mixing model between Nile sediment and Saharan dust has been used to describe the variability of detrital supplies to the Levantine Basin for the present-day (Krom et al., 1999a; Weldeab et al., 2002a) and for the last $100 \mathrm{ka}$ (Krom et al., 1999b; Freydier et al., 2001; Revel et al., 2010, 2015). Using Sr-Nd isotope data, the lateQuaternary detrital sediments deposited in the Aegean Sea have also been reported to be a mixture of Aegean/Nile river-borne materials and Saharan dust (Weldeab et al., 2002b; Ehrmann et al., 2007b).

For the central Mediterranean, the system seems to be more complex. Based on the surface distribution of Sr-Nd isotopes, not only the Saharan dust and the NBEM riverine supplies have been reported, but also a potential influence from the Libyan margin has been inferred for the present-day Ionian Sea (Weldeab et al., 2002a). Moreover, a local riverine source to the Ionian Sea has been suggested for the S1 time, but with unspecified origin and geochemical signature (Fontugne et al., 1994; Krom et al., 1999b; Freydier et al., 2001; Scrivner et al., 2004).

For our data, it is clear that a third component is required to explain the Holocene deposition in the Ionian Sea (Figs. 5-7). With reference to the published isotopic and elemental data over the 
Table 2

$\mathrm{Sr}$ and Nd isotopic compositions of detrital sediments in core CP10BC.

\begin{tabular}{llllll}
\hline Depth $(\mathrm{cm})$ & Age $(\mathrm{ka})$ & $\mathrm{Sr}(\mathrm{ppm})$ & ${ }^{87} \mathrm{Sr} /{ }^{86} \mathrm{Sr}^{\mathrm{a}}$ & ${ }^{143} \mathrm{Nd} /{ }^{144} \mathrm{Nd}^{\mathrm{b}}$ & $\varepsilon_{\mathrm{Nd}(0)} \pm 2 \sigma^{\mathrm{c}}$ \\
\hline $0-0.25$ & 0.1 & 130.6 & 0.719740 & 0.512027 & $-11.9 \pm 0.31$ \\
$3-3.25$ & 1.0 & 124.1 & 0.719847 & 0.512022 & $-12.0 \pm 0.22$ \\
$6-6.25$ & 1.9 & 186.8 & 0.714879 & 0.512029 & $-11.9 \pm 0.29$ \\
$9-9.25$ & 2.8 & 166.2 & 0.715315 & 0.512029 & $-11.9 \pm 0.22$ \\
$12-12.25$ & 3.6 & 140.1 & 0.718365 & 0.512016 & $-12.1 \pm 0.23$ \\
$15-15.25$ & 4.5 & 120.2 & 0.719703 & 0.512039 & $-11.7 \pm 0.23$ \\
$17-17.25$ & 5.1 & 120.1 & 0.717723 & 0.512047 & $-11.5 \pm 0.28$ \\
$17.5-17.75$ & 5.2 & 113.9 & 0.718582 & 0.512046 & $-11.5 \pm 0.22$ \\
$18.25-18.5$ & 5.4 & 118.0 & 0.718113 & 0.512043 & $-11.6 \pm 0.22$ \\
$19-19.25$ & 5.6 & 110.3 & 0.717853 & 0.512054 & $-11.4 \pm 0.22$ \\
$19.75-20$ & 5.8 & 111.1 & 0.717317 & 0.512066 & $-11.2 \pm 0.24$ \\
$21.25-21.5$ & 6.2 & 118.1 & 0.716946 & 0.512061 & $-11.3 \pm 0.17$ \\
$22-22.25$ & 6.4 & 131.6 & 0.716631 & 0.512071 & $-11.1 \pm 0.38$ \\
$22.75-23$ & 6.5 & 133.8 & 0.716065 & 0.512071 & $-11.1 \pm 0.21$ \\
$24-24.25$ & 6.8 & 138.0 & 0.715476 & 0.512076 & $-11.0 \pm 0.26$ \\
$24.5-24.75$ & 7.0 & 142.0 & 0.715471 & 0.512079 & $-10.9 \pm 0.22$ \\
$26-26.25$ & 7.3 & 141.9 & 0.714622 & 0.512092 & $-10.6 \pm 0.22$ \\
$27.5-27.75$ & 7.7 & 135.0 & 0.714916 & 0.512001 & $-11.0 \pm 0.26$ \\
$28-28.25$ & 7.8 & 126.9 & 0.714915 & 0.512069 & $-11.1 \pm 0.22$ \\
$28.5-28.75$ & 7.9 & 127.5 & 0.715166 & 0.512084 & $-10.8 \pm 0.27$ \\
$29.25-29.5$ & 8.1 & 138.5 & 0.714822 & 0.512074 & $-11.1 \pm 0.21$ \\
$30-30.25$ & 8.3 & 123.1 & 0.716075 & 0.512067 & $-11.1 \pm 0.35$ \\
$30.75-31$ & 8.6 & 120.8 & 0.716393 & 0.512066 & $-11.2 \pm 0.22$ \\
$32.25-32.5$ & 9.0 & 122.8 & 0.716694 & 0.511989 & $-11.6 \pm 0.22$ \\
$33.5-33.75$ & 9.3 & 119.0 & 0.716986 & 0.512044 & $-11.6 \pm 0.31$ \\
$34-34.25$ & 9.4 & 114.4 & 0.717473 & 0.512049 & $-11.5 \pm 0.22$ \\
$34.5-34.75$ & 9.6 & 117.9 & 0.718064 & 0.512044 & $-11.7 \pm 0.17$
\end{tabular}

${ }^{a}$ Errors $(2 \sigma)$ are always $<0.00004$, normalized to the NBS-SRM 987 value of ${ }^{87} \mathrm{Sr} /{ }^{86} \mathrm{Sr}=0.705248$ (Thirlwall, 1991).

b Normalized to the JNdi value of ${ }^{143} \mathrm{Nd} /{ }^{144} \mathrm{Nd}=0.512115$ (Tanaka et al., 2000).

c Highest errors of internal and external errors are reported.

circum-Mediterranean (Table 4), we will show that for the past 9.8 ka the Ionian sediment composition can be represented by a threeendmember mixture of detrital supplies derived from Saharan Dust, Aegean/Nile, and Libyan Soil.

\subsubsection{Definition of the two traditional endmembers}

Dust derived from North Africa is a significant component to the EMS. Our radiogenic isotope results yield a "Saharan Dust" endmember, with values that are typical for central Sahara-derived dust/aerosols collected over the EMS (see reviews by Grousset and Biscaye, 2005; Scheuvens et al., 2013) (Table 4; Figs. 6 and 7). Consistent low $\mathrm{Ti} / \mathrm{Al}$ and $\mathrm{Zr} / \mathrm{Al}$ values during the humid climate, sapropel S1 interval, and high values for the arid periods, are in agreement with a dominant Saharan dust input (e.g. Wehausen and Brumsack, 1999, 2000; Nijenhuis and de Lange, 2000; Lourens et al., 2001). Titanium and $\mathrm{Zr}$ mainly reside in heavy minerals and can be transported with coarse quartz in wind-blown Saharan materials (see Scheuvens et al., 2013).

At present, riverine supplies to the central Mediterranean are low compared to eolian fluxes (Guerzoni et al., 1997; Rutten et al., 2000). Using Sr and Nd isotopes, it has been shown that minor amounts of Nile sediments - if any - may be deposited in the areas west of Crete (Krom et al., 1999a; Weldeab et al., 2002a) (c.f. Section 2). At sapropel times, the enhanced Nile sediment load has been geographically limited. Comparisons across the Nile delta show that higher sedimentation rates during sapropel S1 occurred only for cores taken close to the delta (Hennekam et al., 2015), indicating that the offshore spread of Nile particulate matter was not larger. Moreover, increased precipitation is thought to have generated denser vegetation causing reduced physical erosion in the Ethiopian highlands (Blue Nile source), which yields most of the Nile particulates (Krom et al., 1999b; Weldeab et al., 2002b). This is supported by the systematically lower $\mathrm{Ti} / \mathrm{Al}$ ratios observed in the
Levantine Basin during sapropel times (e.g. Krom et al., 1999b; Wehausen and Brumsack, 1999, 2000; Box et al., 2011; Hennekam et al., 2014). The higher Ti/Al in sapropels for the western Niledelta (Revel et al., 2010; see also Hennekam et al., 2015) has been interpreted by Box et al. (2011) as overbank flood deposits from turbidity flows, which mainly reflect the magnitude of water flow. Box et al. (2011) also suggested that during S1 time the Nile sediment reaching distal locations within the Levantine Basin, was mainly from the White Nile, since the Sudd swamps no longer acted as a giant sediment trap (Williams et al., 2000). However, a simple dichotomy between riverine inputs from the Blue Nile and Atbara and Saharan dust fluxes has been recently shown by the ${ }^{87} \mathrm{Sr} /{ }^{86} \mathrm{Sr}$ and $\varepsilon_{\mathrm{Nd}(0)}$ ratios of two cores from the Nile upper continental slope (Revel et al., 2015). This confirms that the sediment contribution from the White Nile has been minor for the last 25 ka (Revel et al., 2015).

In any case, the White Nile should not have constituted a considerable source for sapropel S1 sediment of core CP10BC in the distant southwestern Ionian, as explicitly discounted by the diagram of ${ }^{87} \mathrm{Sr} /{ }^{86} \mathrm{Sr}$ vs. $1000 / \mathrm{Sr}$ (Fig. 7). Particularly, the surface-water pathway (Fig. 1) strongly argues against contributions from the White Nile source. Considering the position of core CP10BC along the MAW pathway, rivers from the NBEM should be more important than the Nile as potential detrital source during humid sapropel periods (Fig. 1).

Here, we refer to the endmember with lowest ${ }^{87} \mathrm{Sr} /{ }^{86} \mathrm{Sr}$ and highest $\varepsilon_{\mathrm{Nd}(0)}$ ratios as "Aegean/Nile" in core CP10BC (Table 4; Figs. 6 and 7). Its $\mathrm{Sr}$ and $\mathrm{Nd}$ isotopic compositions and Sr contents are taken from average values of Balkan and Aegean basalt and main Nile, representing river-borne particulates from the NBEMand/or Nile (Table 4; Figs. 6 and 7). This is because riverine inputs from Nile and Aegean regions cannot be differentiated due to the similar Sr-Nd isotopic signatures (Weldeab et al., 2002a, 2002b). In addition, this signature is quite similar for the Aegean and most other NBEM areas (Klaver et al., 2015).

The elemental composition of sediments in core CP10BC can, nevertheless, shed light on the relative contributions. The pattern of lower (higher) Ti/Al values in sapropel S1 (non-sapropel) and the similarity between $\mathrm{Ti} / \mathrm{Al}$ and $\mathrm{Zr} / \mathrm{Al}$ profiles in core $\mathrm{CP} 10 \mathrm{BC}$ indicate that most of the Ti/Al signal is derived from Saharan dust, rather than from Nile sediment (Fig. 4). From the plot of Ti/Al vs. K/Al (Fig. 5a) it is also clear that only the NBEM (i.e. Aegean and Adriatic) riverine inputs can account for the increased $\mathrm{K} / \mathrm{Al}$ ratio during sapropel S1 time in the Ionian Sea; an increased Nile sediment contribution can be ruled out as this is characterized by very low $\mathrm{K} /$ Al. This means that during sapropel S1, the NBEM riverine input is a major component of the Aegean/Nile endmember, whereas the Nile contribution is minor.

The enhanced K/Al associated with NBEM riverine input for sapropel layers has been report to correspond with a higher illite content (see Martinez-Ruiz et al., 2015). The clay mineral assemblage is known to be related to provenance and hydrological environmental conditions (e.g. Chamley, 1989; Wu et al., 2012; Bout-Roumazeilles et al., 2013). A north-south contrast in hydroclimate conditions has been proposed for the Holocene central Mediterranean (see review by Magny et al., 2013). The K/Al profile of core CP10BC displays good correspondence with the precipitation reconstructions north of $40^{\circ} \mathrm{N}$ (Figs. 1 and 9): speleothem $\delta^{18} \mathrm{O}$ data of Corchia Cave reflecting regional precipitation (Zanchetta et al., 2007) and pollen-based estimates of winter precipitation in Lake Accesa (Peyron et al., 2011). On the other hand, the areas south of $40^{\circ} \mathrm{N}$ (e.g. Lake Pergusa in Sicily) are characterized by persistently humid winters and summers until $5.0 \mathrm{ka}$ (see Magny et al., 2013), coinciding with the K/Al minima in core CP10BC. Taken together, the $\mathrm{K} / \mathrm{Al}$ in core $\mathrm{CP} 10 \mathrm{BC}$ is considered to be related to 


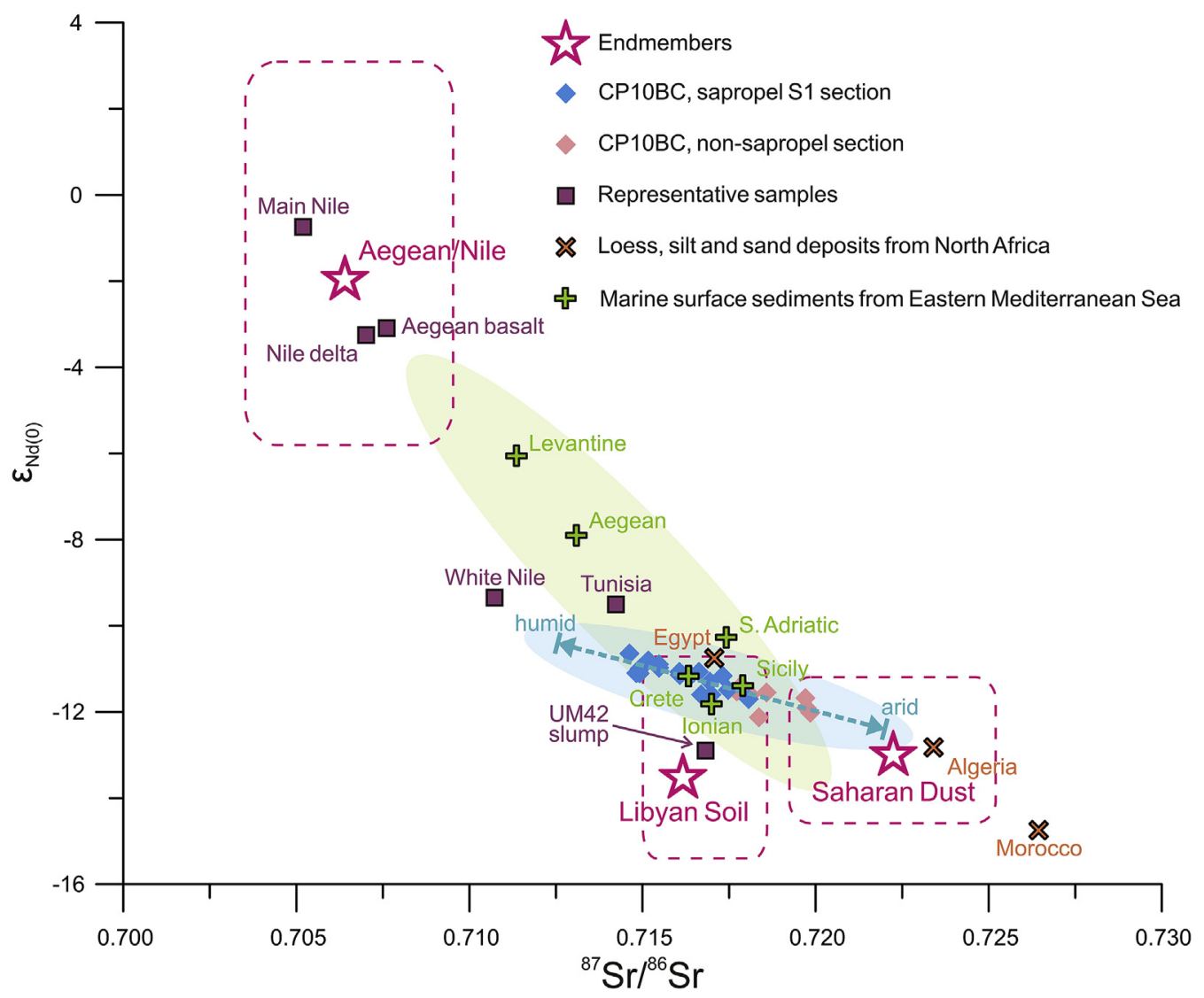

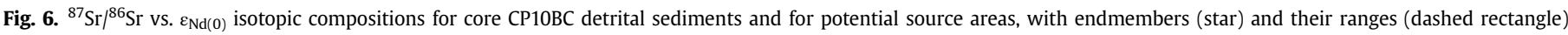

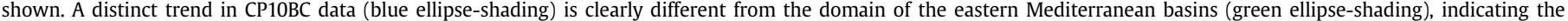

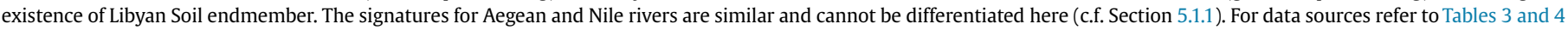

winter precipitation and associated riverine inputs from the NBEM during S1 deposition.

\subsubsection{Evidence for the Libyan endmember}

In the diagnostic plot of ${ }^{87} \mathrm{Sr} /{ }^{86} \mathrm{Sr}$ vs. $\varepsilon_{\mathrm{Nd}(0)}$ for the central Mediterranean sediments and in particular those of core CP10BC, a third component with a Sr-Nd isotopic composition different from the traditional provenance fields is expected (Fig. 6). A similar observation can be made on the basis of the ${ }^{87} \mathrm{Sr} /{ }^{86} \mathrm{Sr}-1000 / \mathrm{Sr}$ diagram; that is, the data cannot be described by a simple twoendmember mixing model (Fig. 7).

As shown in Fig. 6, the $\mathrm{Sr}$ and $\mathrm{Nd}$ isotopic values of detrital sediments within core $\mathrm{CP} 10 \mathrm{BC}$ display a distinctive trend. The nonsapropel samples would still fit along the two-endmember mixing trend between Saharan Dust and Aegean/Nile. However, the samples deposited during the humid S1-interval clearly indicate an additional source with a simultaneous low ${ }^{87} \mathrm{Sr} /{ }^{86} \mathrm{Sr}$ and $\varepsilon_{\mathrm{Nd}(0)}$. The $\mathrm{Sr}-\mathrm{Nd}$ isotopic array also reveals that enhanced contributions from this source and that of Aegean/Nile occurred at the same time, relative to a reduced supply of Saharan Dust, suggesting a riverineorigin for the inferred source. Comparing the Sr-Nd isotopic ratios for all potential source areas (Table 4; Figs. 1 and 6), this endmember can best be attributed to "Libyan Soil" (Grousset and Biscaye, 2005; Revel et al., 2010).

A ternary mixing system is also present for the elemental compositions of sediments in core CP10BC. The data of $\mathrm{Ti}$ and $\mathrm{K}$ suggest three different hydroclimate conditions of sediment transport and deposition, and this compositional variability can be best explained by mixing between at least three endmembers
(Fig. 5). As discussed above, Saharan dust and NBEM riverine supplies are amongst the endmembers, with negligible Nile influence (c.f. Section 5.1.1). As indicated by decreasing Ti/Al and $\mathrm{K} / \mathrm{Al}$ ratios, the evolution trend of CP10BC data from S1a to S1b suggests the existence of a third endmember (Figs. 4 and 5). Despite the lack of adequate elemental data for the Libyan hinterland, this observation and the concurrent higher sedimentation rate (Fig. 2 ) is interpreted here to indicate an enhanced contribution of Libyan Soil material during the S1b interval. This contribution is characterized by relatively low $\mathrm{Ti} / \mathrm{Al}$ and $\mathrm{K} / \mathrm{Al}$ ratios. Note that in general a spurious correlation may be discerned when using a plot of normalized elements (see Van der Weijden, 2002). In core CP10BC, however, the evolution trend in the Ti vs. $\mathrm{K}$ plot (Fig. 5b) confirms and even better visualizes the pattern observed in the plot of Ti/Al vs. K/Al (Fig. 5a), which justifies the evaluation of potential source areas made above.

Although the detrital $\mathrm{Sr}$ isotopic composition could be influenced by grain-sized sorting and possible barite-Sr, plotting of ${ }^{87} \mathrm{Sr} /{ }^{86} \mathrm{Sr}$ ratios against $1000 / \mathrm{Sr}$ concentrations has been widely used for provenance discrimination, especially in the circumMediterranean area (e.g. Grousset et al., 1992, 1998; Krom et al., 1999a, 1999b; Grousset and Biscaye, 2005; Box et al., 2011). Indeed, the patterns of trend and timing presented in the ${ }^{87} \mathrm{Sr} /{ }^{86} \mathrm{Sr}-1000 / \mathrm{Sr}$ diagram (Fig. 7) do corroborate this interpretation, showing the highest contribution of Libyan Soil between 6.3 and $5.5 \mathrm{ka}$. It seems that during the onset $(\sim 9.8-8.3 \mathrm{ka})$ and ending $(\sim 6.3-5.5 \mathrm{ka})$ of S1, the relative contribution from Libyan rivers was more pronounced, whereas during mid-S1 it is rather the NBEM contribution that dominated (Fig. 7). Further work is required to 


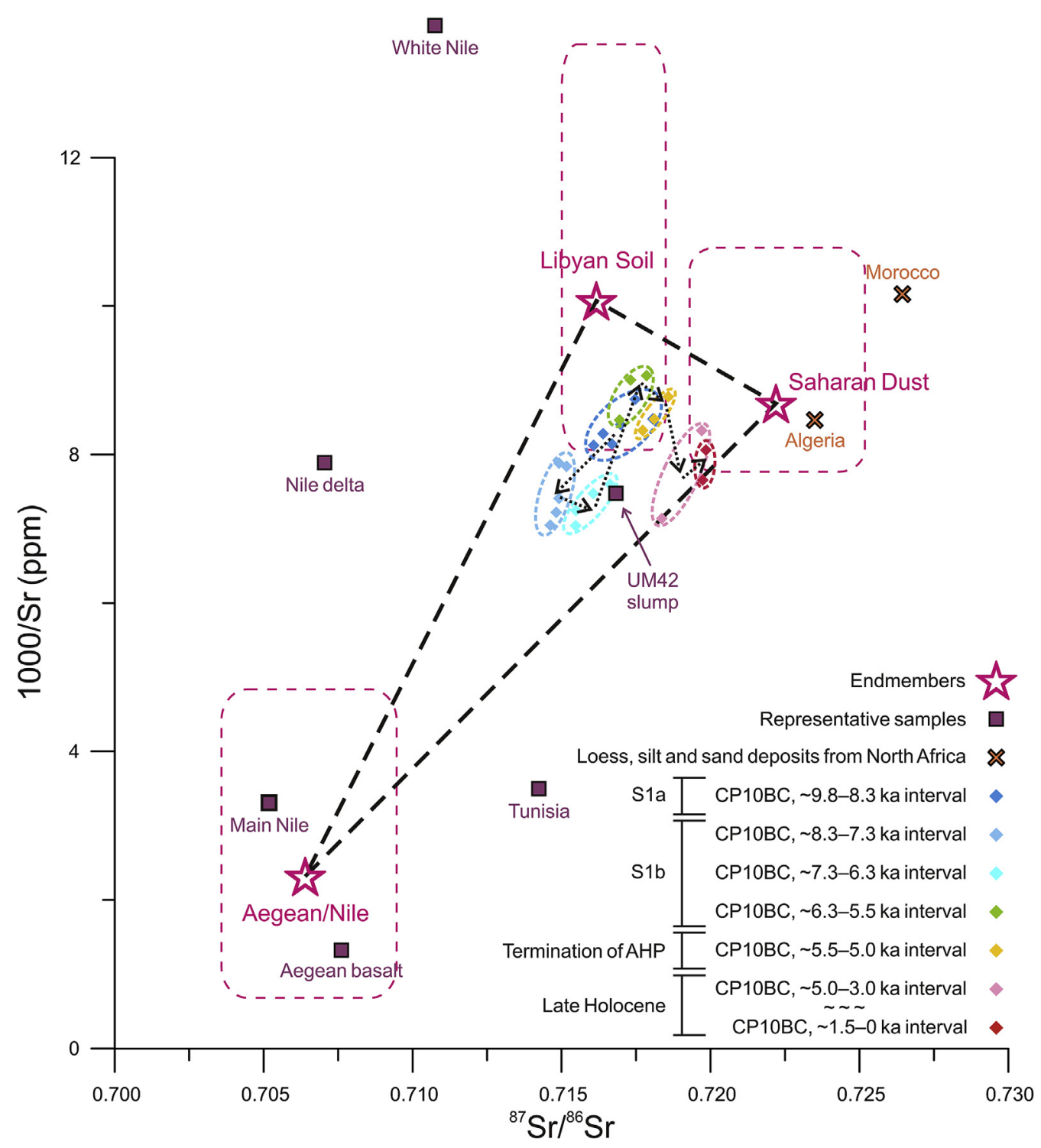

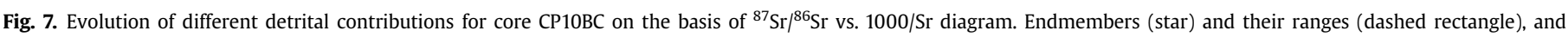

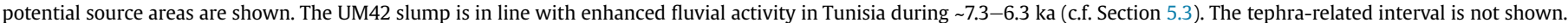
For data sources see Tables 3 and 4.

Table 3

$\mathrm{Sr}$ and Nd isotopic compositions of detrital sediments in core SL114. ${ }^{\mathrm{a}}$

\begin{tabular}{lllll}
\hline Depth $(\mathrm{cm})$ & Sample ${ }^{\mathrm{b}}$ & ${ }^{87} \mathrm{Sr} /{ }^{86} \mathrm{Sr}$ & ${ }^{143} \mathrm{Nd} /{ }^{144} \mathrm{Nd}$ & $\varepsilon_{\mathrm{Nd}(0)}$ \\
\hline 0.25 & non-S1 & 0.718895 & 0.512019 & -12.1 \\
15.55 & non-S1 & 0.718905 & 0.512013 & -12.2 \\
24.05 & $\mathrm{~S} 1$ & 0.716694 & 0.512111 & -10.3 \\
28.05 & $\mathrm{~S} 1$ & 0.715441 & 0.512123 & -10.1 \\
32.05 & $\mathrm{~S} 1$ & 0.715743 & 0.512113 & -10.2 \\
34.05 & $\mathrm{~S} 1$ & 0.716405 & 0.512083 & -10.8 \\
39.05 & non-S1 & 0.716243 & 0.512072 & -11.0 \\
49.2 & non-S1 & 0.718041 & 0.512074 & -11.0 \\
\hline
\end{tabular}

${ }^{\text {a }}$ Uncertainty $(2 \sigma)$ of ${ }^{87} \mathrm{Sr} /{ }^{86} \mathrm{Sr}$ and ${ }^{143} \mathrm{Nd} /{ }^{144} \mathrm{Nd}$ are 0.000015 and 0.000010 , respectively. See Freydier et al. (2001) for analytical details.

$\mathrm{b}$ Identification of $\mathrm{S} 1$ is based on $\mathrm{Ba} / \mathrm{Al}$ profile.

verify and quantify this observation, but a Libyan riverine supply during S1b must have been considerable. This increased detrital supply could be related to the simultaneously intensified dynamics of river/wadi systems draining Tunisia and western Libya (Zielhofer et al., 2008). An enhanced detrital input of Sr-rich aragonite from the Libyan coastal areas during S1 has also been suggested (Reitz and de Lange, 2006).

Our observations are consistent with previous reconstructions of North-African monsoon precipitation. Stratigraphic surveys and pollen analysis on palustrine and eolian sediments for the Jefara Plain suggest a wet Holocene until $\sim 5.0 \mathrm{ka}$, interrupted by two arid spells dated $\sim 8.2$ and $5.4 \mathrm{ka}$, with the most humid conditions occurring between $\sim 6.8$ and $5.5 \mathrm{ka}$ (Giraudi et al., 2013) (Figs. 1 and $9 h$ ). Archaeological surveys also indicate the same pattern. Persistently denser population in Libya between $\sim 7.5$ and 6.0 ka and densest population around 6.0 ka have been shown (Manning and Timpson, 2014), coherent with the Libyan hydroclimate evolution and the changes in Libyan Soil observed in core CP10BC. The steady humid phase $(\sim 6.7-5.4 \mathrm{ka})$ in northwestern Libya is also identified through the presence of large ponds and marshes (Barich, 2014).

In conclusion, our results indicate important riverine supplies from Libya to the Ionian Sea, accompanied by a simultaneous increase in the NBEM contribution. This riverine detrital supply is 


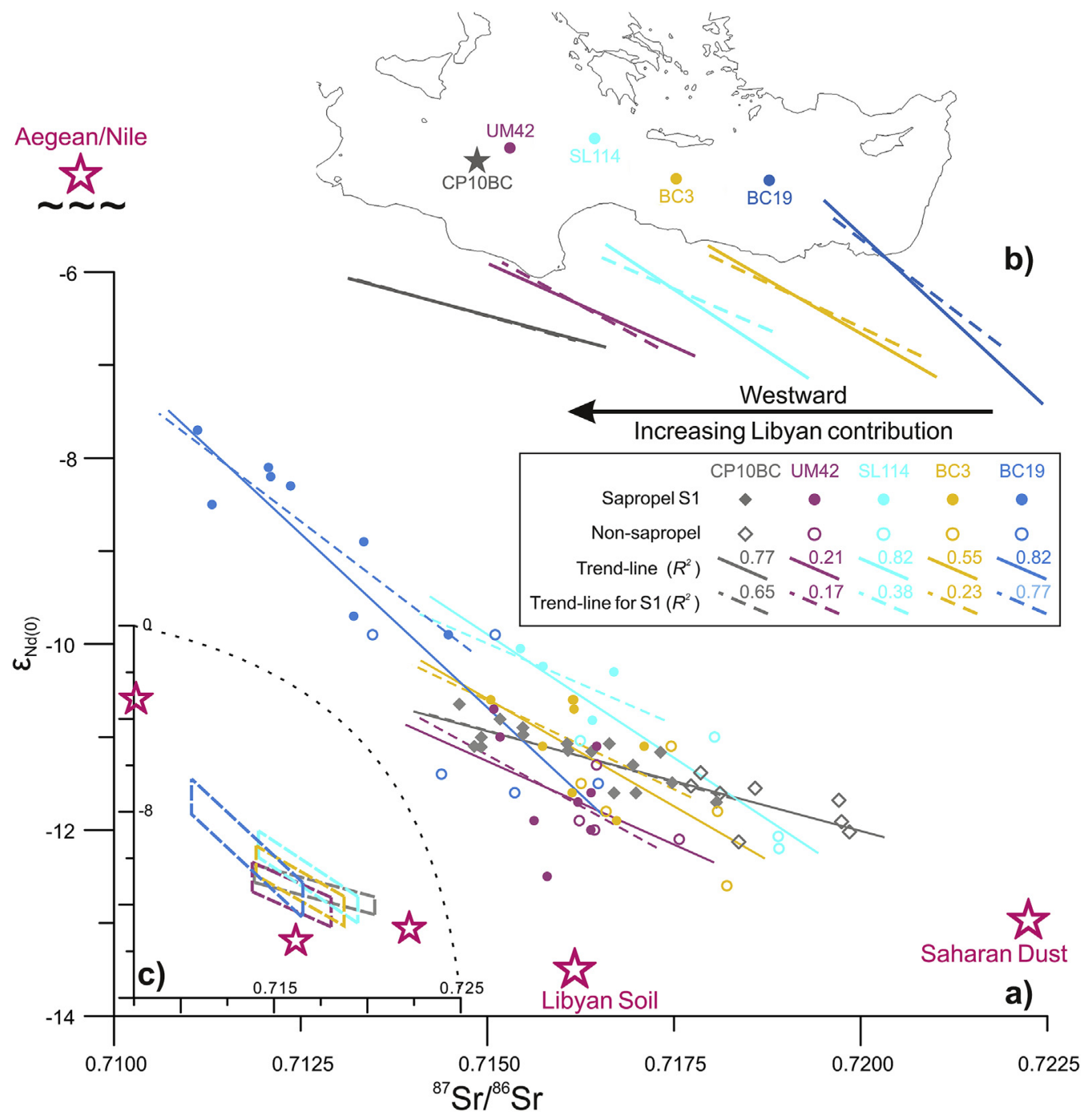

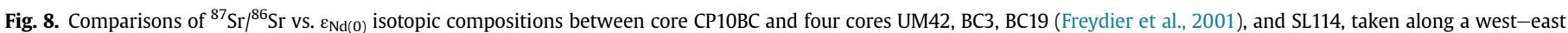

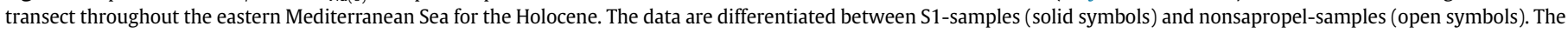

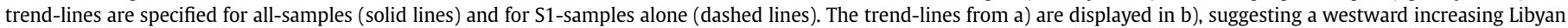
Soil contribution. c) Dashed parallelograms profile the data range for each core.

characterized by relatively low ${ }^{87} \mathrm{Sr} /{ }^{86} \mathrm{Sr}(\sim 0.716)$ and $\varepsilon_{\mathrm{Nd}(0)}(-13.5)$ values, as well as low Ti/Al $(<0.05)$ and $\mathrm{K} / \mathrm{Al}(<0.25)$ ratios. The riverine contribution from the Libyan margin is controlled by North-African monsoon precipitation. It was most enhanced during sapropel S1b in particular, with the highest contribution between $\sim 6.3$ and $5.5 \mathrm{ka}$.

\subsection{A west-east comparison throughout the eastern Mediterranean Sea}

At sapropel times, enhanced African monsoon precipitation activated fossil river/wadi systems along the wider North-African margin, which could deliver substantial amounts of freshwater and detrital material to the EMS. This has been proposed previously for the sapropel S5 (Rohling et al., 2002; c.f. Section 1). We demonstrate that such scenario has occurred also for sapropel S1. The fossil river/wadi channel network in eastern Libya towards the Gulf of Sirte has been considered as an important detrital source during deposition of sapropel S5 (Rohling et al., 2002, 2004; Osborne et al., 2008, 2010) (Fig. 1). The satellite imagery of its major paleo-river channels lends support to the idea of a humid corridor (Paillou et al., 2009, 2012). Yet, this consideration on the origin of the riverine supply may not be fully adequate due to the limited spatial coverage of the studied sites. In other words, none of the reported sites can distinguish between the supplies from western and eastern Libya. In fact, with three major paleo-river systems identified, Coulthard et al. (2013) have revealed that it is the most-western paleo-river system flowing over western Libya and Tunisia that represents the most likely route for human migration across the Sahara (Fig. 1).

To evaluate the potential distribution of the Libyan detrital supply and to locate potential riverine sources, we compare the $\mathrm{Sr}$ and $\mathrm{Nd}$ isotope data of core $\mathrm{CP} 10 \mathrm{BC}$ with those of four cores taken along a west-east transect throughout the EMS.

\subsubsection{Distribution of the Libyan detrital supply}

Cores UM42, SL114, BC3, and BC 19 were collected in the western, eastern Ionian Sea, the south of Crete, and the Levantine Basin, respectively (Freydier et al., 2001) (Fig. 1). The Sr and Nd isotope data for these cores display distinct trends (Fig. 8). For the recent sediments, the values of ${ }^{87} \mathrm{Sr} /{ }^{86} \mathrm{Sr}$ and $\varepsilon_{\mathrm{Nd}(0)}$ in cores UM42, SL114, and BC3 are similar to those of core CP10BC, indicating a 
Table 4

Published $\mathrm{Sr}$ contents, ${ }^{87} \mathrm{Sr} /{ }^{86} \mathrm{Sr}$ ratios, and $\varepsilon_{\mathrm{Nd}(0)}$ values of samples from the circum-Mediterranean.

\begin{tabular}{|c|c|c|c|c|c|c|c|c|c|}
\hline \multirow[t]{2}{*}{ Sample $^{a}$} & \multirow[t]{2}{*}{ Sample type } & \multirow[t]{2}{*}{ Sample number } & \multicolumn{2}{|l|}{$\mathrm{Sr}(\mathrm{ppm})$} & \multicolumn{2}{|l|}{${ }^{87} \mathrm{Sr} /{ }^{86} \mathrm{Sr}$} & \multicolumn{2}{|l|}{$\varepsilon_{\mathrm{Nd}(0)}$} & \multirow[t]{2}{*}{ Source $^{b}$} \\
\hline & & & Average & Range & Average & Range & Average & Range & \\
\hline Saharan Dust ${ }^{c}$ & Loess, silt and sand deposits & 9 & 115.1 & $92.5-128.6$ & 0.722243 & $0.719251-0.725225$ & -13.0 & $-14.6-11.2$ & 1 \\
\hline Aegean/Nile ${ }^{\mathrm{d}}$ & & & 528.5 & $206.0-1426.0$ & 0.706394 & $0.703527-0.709529$ & -1.9 & $-5.8-3.1$ & \\
\hline Aegean basalt & Tertiary basalt rocks & 33 & 754.7 & $206.0-1426.0$ & 0.707610 & $0.703527-0.709529$ & -3.1 & $-5.8-3.1$ & 2 \\
\hline Main Nile & Levee mud & 10 & 302.2 & $269.0-331.0$ & 0.705177 & $0.704690-0.705660$ & -0.7 & $-2.9-1.7$ & 3 \\
\hline White Nile ${ }^{e}$ & Bank mud & 3 & 72.5 & & 0.710750 & $0.710450-0.710970$ & -9.4 & $-10.4-8.6$ & 3,4 \\
\hline Nile delta & Delta sediments & 3 & 126.7 & $116.6-140.3$ & 0.707043 & $0.706470-0.707530$ & -3.3 & & after 5 \\
\hline UM42 slump ${ }^{\mathrm{f}}$ & Libyan-Tunisian shelf slump & 1 & 133.7 & & 0.716830 & & -12.9 & & 6 \\
\hline Levantine & Marine surface sediments & 17 & & & 0.711363 & $0.707531-0.714959$ & -6.1 & $-10.3-1.0$ & $5,6,7,8$ \\
\hline Aegean & Marine surface sediments & 8 & & & 0.713090 & $0.710380-0.713831$ & -7.9 & $-8.8-5.8$ & $5,8,9$ \\
\hline Crete & Marine surface sediments & 5 & & & 0.716329 & $0.715968-0.716950$ & -11.2 & $-11.5-10.9$ & 5 \\
\hline Ionian & Marine surface sediments & 7 & & & 0.716998 & $0.715924-0.718895$ & -11.8 & $-12.5-11.0$ & 5,8 \\
\hline S. Adriatic & Marine surface sediments & 4 & & & 0.717427 & $0.716887-0.718342$ & -10.3 & $-11.8-9.6$ & 5,8 \\
\hline Sicily & Marine surface sediments & 3 & & & 0.717906 & $0.715700-0.720086$ & -11.4 & $-12.1-10.9$ & 5 \\
\hline Libyan Soil' ${ }^{g}$ & Loess, silt and sand deposits & 10 & 99.3 & $73.8-124.1$ & 0.716165 & $0.715000-0.718597$ & -13.5 & $-15.4-10.7$ & 1,7 \\
\hline Tunisia & Loess, silt and sand deposits & 1 & 286.0 & & 0.714239 & & -9.5 & & 10 \\
\hline Egypt & Loess, silt and sand deposits & 2 & & & 0.717072 & $0.715874-0.718270$ & -10.8 & $-11.0-10.5$ & 1 \\
\hline Algeria & Loess, silt and sand deposits & 3 & 118.1 & $21.1-168.6$ & 0.723500 & $0.721000-0.726000$ & -12.8 & $-12.1-13.5$ & after 11 \\
\hline Morocco & Loess, silt and sand deposits & 4 & 98.4 & $87.2-111.6$ & 0.726441 & $0.716593-0.734041$ & -14.8 & $-17.1-11.8$ & 12 \\
\hline
\end{tabular}

a All samples are decarbonated, except Aegean basalt, main Nile and White Nile, of which carbonate content $<2 \%$; endmembers are in bold.

b 1 = Grousset and Biscaye (2005), 2 = Güleç (1991), 3 = Padoan et al. (2011), $4=$ Box et al. (2011), $5=$ Weldeab et al. (2002a), $6=$ Freydier et al. (2001), $7=$ Revel et al. (2010), 8 = Tachikawa et al. (2004), $9=$ Ehrmann et al. (2007b), $10=$ Grousset et al. (1992), $11=$ Scheuvens et al. (2013), 12= Grousset et al. (1998).

c $\mathrm{Sr}$ is taken from modern Saharan aerosols collected in Corsica $\left(\sim 42^{\circ} \mathrm{N}, 9^{\circ} \mathrm{E}\right)$.

d Average of Aegean basalt and Main Nile.

e ${ }^{87} \mathrm{Sr} /{ }^{86} \mathrm{Sr}$ and $\varepsilon_{\mathrm{Nd}(0)}$ from 3, while $\mathrm{Sr}$ after 4

${ }^{\mathrm{f}}$ Identified by the inversion of depth-AMS ${ }^{14} \mathrm{C}$ ages.

g $\mathrm{Sr}$ from 6 alone, while ${ }^{87} \mathrm{Sr} /{ }^{86} \mathrm{Sr}$ and $\varepsilon_{\mathrm{Nd}(0)}$ after 1 and 6 . Only the plotted data in 6 are used.

similar predominant Saharan dust source. It must be noted that a slight west-east decrease in dust ${ }^{87} \mathrm{Sr} /{ }^{86} \mathrm{Sr}$ ratio may occur (see Krom et al., 1999a).

It has been suggested that increased riverine flux and decreased eolian flux must have occurred together during sapropel deposition (e.g. Krom et al., 1999b; Wehausen and Brumsack, 1999, 2000; Freydier et al., 2001). Indeed, the Sr-Nd isotopic arrays all show that during S1 time, contributions from Aegean/Nile and Libyan Soil increased, relative to a concomitantly reduced Saharan Dust supply (Fig. 8). Specifically, cores CP10BC and UM42 point to a Libyan Soil dominated contribution, whereas SL114 shows a higher contribution from an Aegean/Nile source. This is in agreement with the location of core SL114, being more distant from the Libyan margin and more proximal to the NBEM area. Moreover, the overall higher ${ }^{87} \mathrm{Sr} /{ }^{86} \mathrm{Sr}-\varepsilon_{\mathrm{Nd}(0)}$ signatures for core SL114 compared to eastern sites BC3 and BC19 indicates a NBEM source rather than the Nile for the Aegean/Nile endmember (Fig. 8c). In the Levantine Basin, the variability of $\mathrm{Sr}-\mathrm{Nd}$ isotopic compositions has been attributed to a binary mixing between Saharan dust and Nile sediment (e.g. Krom et al., 1999b; Revel et al., 2010, 2015). This can be clearly seen in core $\mathrm{BC} 19$, the easternmost site. This confirms the predominant Aegean/Nile riverine inputs while the potential Libyan contribution seems to have nearly disappeared.

The overall trend towards the humid-most sapropel phase, indicates a decreasing Libyan Soil contribution from southern to northern Ionian (i.e. from CP10BC towards UM42, SL114), and from the Ionian eastward to Levantine (i.e. from CP10BC towards BC3 and BC19) (Fig. 8). The decreasing contribution of Libyan Soil may be due to a decreasing flux, and/or relatively increasing fluxes from other provenances (i.e. NBEM and Nile).

The systematic west-east increase in the slope of $\mathrm{Sr}-\mathrm{Nd}$ isotopic arrays within each of these five cores throughout the EMS is estimated to reflect a higher contribution from Libya in the western section and a more pronounced Nile contribution in the eastern part (Fig. 8b). If this holds true, this feature points to the eastward flowing of suspended Libyan riverine material (presumably with
MAW) and/or the westward transport of Nile-derived particulates (presumably with LIW).

\subsubsection{Origin of the Libyan detrital supply}

The Libyan detrital supply could originate from 1 ) eastern Libya as suggested for sapropel S5 (Rohling et al., 2002; Osborne et al., 2008), redistributed by the anticyclonic surface-currents on the Libyan shelf, or 2) from the west, transported by the MAW from the broad Libyan-Tunisian shelf (Fig. 1). The lower contribution of Libyan Soil for core $\mathrm{BC} 3$ relative to $\mathrm{CP} 10 \mathrm{BC}$ suggests that the major source is western Libya rather than eastern Libya; but this could also be related to a more prominent Aegean/Nile influence for BC3, and depends on the transport pathways (Figs. 1 and 8).

Comparison between cores CP10BC and UM42 can give more precise constraints. The $\mathrm{Sr}-\mathrm{Nd}$ isotope data of core UM42 are generally closer to the Libyan Soil endmember (Fig. 8), suggesting that the Libyan detrital supply has affected core UM42 more than others. In contrast to the other four cores, the UM42 data, especially for S1-samples, including an identified slump, are characterized by a scattered distribution, implying a more dynamic depositional condition (Table 4; Figs. 6 and 8). Moreover, core UM42 has a flatter ${ }^{87} \mathrm{Sr} /{ }^{86} \mathrm{Sr}-\varepsilon_{\mathrm{Nd}(0)}$ trend-line for all-samples than for S1-samples alone; this is different from the pattern in the other cores, having trend-lines that are flatter for S1-samples than for all-samples (Fig. 8b). Taken together, it seems that such detrital supply may not only be related to direct riverine sources but could as well be derived from shelf deposits. With similar water-depths (1501 vs. $1375 \mathrm{~m}$ for $\mathrm{CP} 10 \mathrm{BC}$ and UM42 respectively), and given the locations of these two cores relative to the potential pathways (i.e. anticyclonic currents vs. MAW) (Fig. 1), we suggest that the Libyan detrital supply is mainly from the west, including riverine inputs and shelfderived fluxes from the Libyan-Tunisian margin.

This concept is consistent with the Sr-Nd isotopic signature of Tunisia (Fig. 6), and supported by several lines of evidence. 1) Paleohydrological and hydraulic modeling have emphasized the paleo-river system (Irharhar) draining western Libya and Tunisia as 


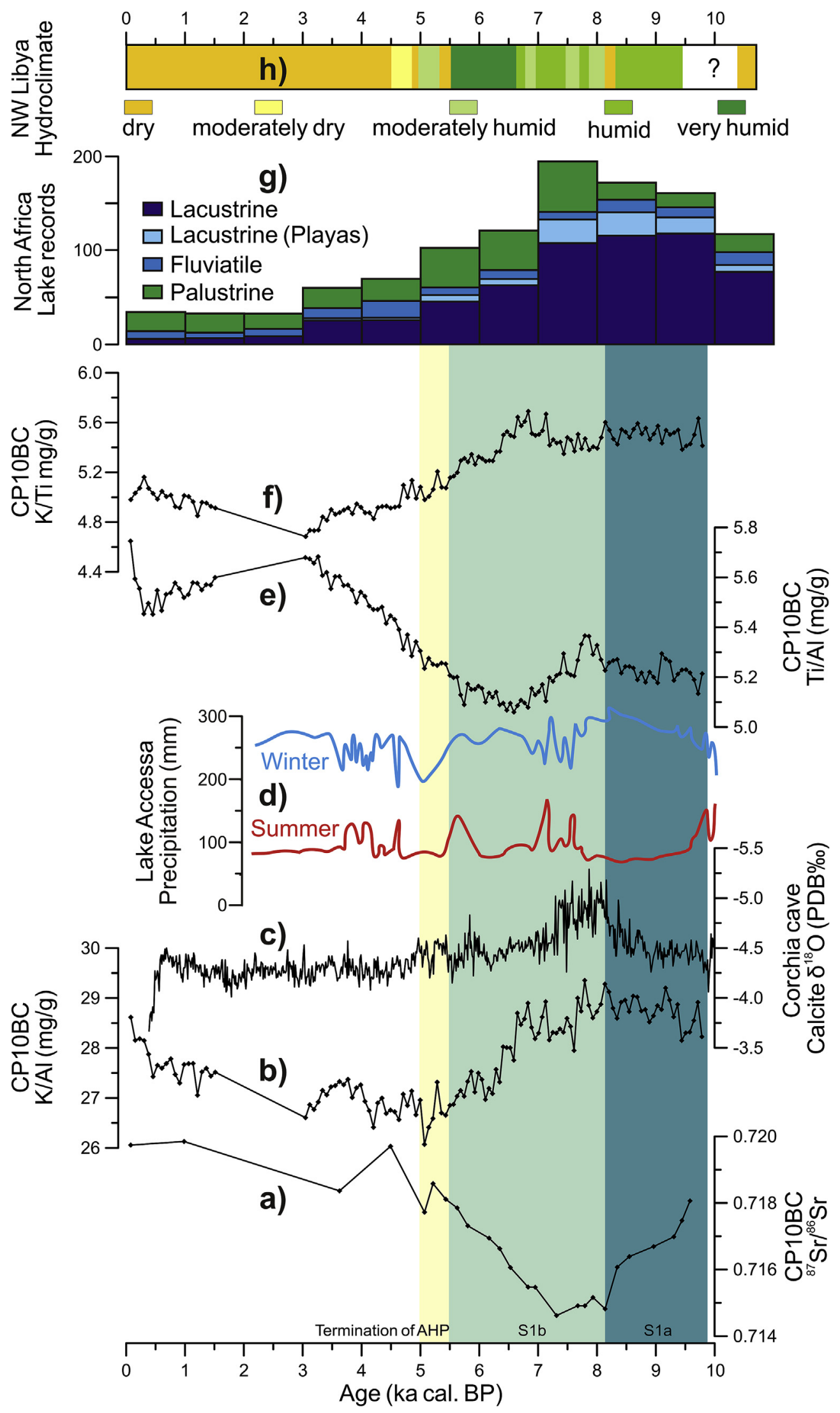

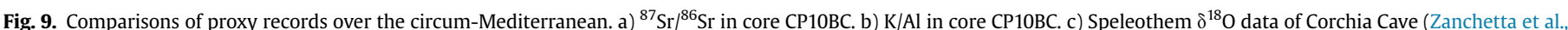

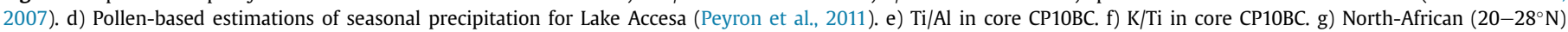

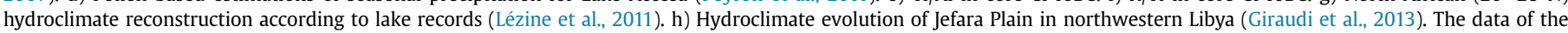
deviating interval ( 3.0-1.5 ka) are removed for core CP10BC. Sapropel S1a, S1b, and termination of AHP (African Humid Period) are indicated. 
a key humid corridor (Coulthard et al., 2013). 2) Based on $>3000$ calibrated ${ }^{14} \mathrm{C}$ dates from $>1000$ archaeological sites over North Africa, Manning and Timpson (2014) revealed a denser population and more frequent migration during the AHP in western than in eastern Libya, concordant with enhanced river-lake systems. 3) A hydroclimate reconstruction of northwestern Libya (Giraudi et al., 2013) appears to be consistent with the changes in the Libyan detrital supply revealed by the ${ }^{87} \mathrm{Sr} /{ }^{86} \mathrm{Sr}-1000 / \mathrm{Sr}$ diagram (Figs. 7 and 9; c.f. Section 5.3). Nevertheless, in view of a potentially different eastern-Mediterranean circulation system during sapropel S1, an (additional) east-Libyan source area cannot be fully excluded.

\subsection{Temporal changes in different detrital contributions in core CP10BC}

Changes in different detrital contributions for core CP10BC associated with hydroclimate conditions can be discerned if detailed information is combined. Overall, the ${ }^{87} \mathrm{Sr} /{ }^{86} \mathrm{Sr}\left(\varepsilon_{\mathrm{Nd}(0)}\right)$ and $\mathrm{K} / \mathrm{Ti}$ profiles exhibit a close correspondence with lake records over North Africa $\left(10-28^{\circ} \mathrm{N}\right)$ (Lézine et al., 2011), indicating that the North-African hydroclimate must have dominated the detrital supplies to the central Mediterranean (Fig. 9a,g). During S1a, riverine inputs from the northern and southern borderlands both increased, as reflected by the decreasing ${ }^{87} \mathrm{Sr} /{ }^{86} \mathrm{Sr}$ and high $\mathrm{K} / \mathrm{Ti}$, corresponding with the North-African lake records and NBEM precipitation proxies, respectively (Fig. 9c,d,f).

Between $~ 8.3$ and 7.3 ka the most humid conditions occurred in the central Mediterranean (Fig. 9), as indicated by various hydroclimate proxy records (e.g. Bar-Matthews et al., 2000; Zanchetta et al., 2007; Peyron et al., 2011; Magny et al., 2013). This can be deduced from the lowest ${ }^{87} \mathrm{Sr} /{ }^{86} \mathrm{Sr}$ and persistent high $\mathrm{K} / \mathrm{Ti}$, and from the ${ }^{87} \mathrm{Sr} /{ }^{86} \mathrm{Sr}-1000 / \mathrm{Sr}$ diagram that indicates increased riverine and decreased eolian contributions for this period (Fig. 7).

From $\sim 7.3$ to $5.5 \mathrm{ka}$, riverine inputs from the NBEM decreased while these from the south increased, as indicated by a progressive increase in ${ }^{87} \mathrm{Sr} /{ }^{86} \mathrm{Sr}$ associated with a decline in $\mathrm{K} / \mathrm{Al}$ and lowest $\mathrm{Ti} /$ $\mathrm{Al}$ (Fig. 9a,b,e). This is consistent with the wettest phase from $\sim 6.5$ to $5.5 \mathrm{ka}$ in northwestern Libya (Fig. 9h).

The deduced decrease in Libyan Soil contribution between $\sim 7.3$ and $6.3 \mathrm{ka}$ (Fig. 7) seems in conflict with the increasing Ti/Al and the wetter conditions in northwestern Libya (Fig. 9e,h). This paradox is thought to be related to additional inputs from Tunisia associated with enhanced fluvial activity between $\sim 6.7$ and $6.0 \mathrm{ka}$ (Zielhofer et al., 2008), in line with the signature of the UM42 slump (Fig. 7). The large shift observed from intervals $\sim 7.3-6.3 \mathrm{ka}$ to $\sim 6.3-5.5$ ka reflects the abrupt withdrawal of the Tunisian inputs and a substantial increase in Libyan Soil contribution, coinciding with the wettest phase in northwestern Libya (Giraudi et al., 2013) (Figs. 7 and 9).

After $\sim 5.5 \mathrm{ka}$, dust supply increased with decreasing riverine inputs (Figs. 7 and 9), associated with the AHP termination; reduced monsoon precipitation resulted in less vegetation cover and the wide occurrence of dry/salt lakes (Lézine et al., 2011; Bard, 2013). The ceasing riverine input from the Libyan-Tunisian margin is shown to be after $\sim 5.0 \mathrm{ka}$ (Fig. 7). Accordingly, after $\sim 1.5 \mathrm{ka}$ the data can be represented by a two-endmember mixing model, analogous to that of the present-day.

\section{Conclusions}

Using $\mathrm{Sr}$ and Nd isotopes supported by major elements ( $\mathrm{Ti}, \mathrm{Zr}, \mathrm{K}$, and $\mathrm{Al}$ ) from core $\mathrm{CP} 10 \mathrm{BC}$, eolian and riverine contributions from North Africa and NBEM to central Mediterranean sediments have been unraveled. For the first time, robust and consistent evidence is given for important riverine supplies from the Libyan-Tunisian margin into the central Mediterranean during sapropel S1 time. Considerable amounts of detrital materials and freshwater must have been delivered into the EMS through the fossil river/wadi systems, which were activated by intensified African monsoon precipitation. The riverine supplies appear to originate mainly from western Libya and Tunisia and were transported as far eastward as $\sim 25^{\circ} \mathrm{E}$. Variations in this riverine contribution show a tight correspondence with hydroclimate evolution of northwestern Libya, with the strongest contribution between $\sim 6.3$ and $5.5 \mathrm{ka}$, indicating a control of the North-African monsoon precipitation on the regional sediment provenance. In addition, it is shown that the Nile influence to the central Mediterranean was negligible whereas a prominent NBEM riverine contribution occurred during sapropel S1 formation, particularly $8.3-7.3 \mathrm{ka}$.

\section{Acknowledgment}

We thank crew and scientists on board the cruises of RV Pelagia CORTADO 2011 and RV Logachev SMILABLE 1999 for collecting cores CP10BC and SL114BC, respectively. We thank Dineke van de MeentOlieman for laboratory assistance, Arnold van Dijk for TOC measurements, Ton Zalm and Helen de Waard for ICP-OES analyses in Utrecht. We are also grateful to Martina Schulz who assisted with column extractions in Oldenburg. Many thanks are given to Antonio Schirone for ${ }^{210} \mathrm{~Pb}$ and ${ }^{137} \mathrm{Cs}$ determinations at ENEA, La Spezia. Two anonymous reviewers are thanked for their constructive comments and suggestions. The China Scholarship Council-Utrecht University PhD Program is acknowledged for financial support (CSC No. 201206260116). JW dedicates this paper to his father, who recently passed away unexpectedly.

\section{References}

Ayache, M., Dutay, J.-C., Arsouze, T., Révillon, S., Beuvier, J., Jeandel, J., 2016. High resolution neodymium characterization along the Mediterranean margins and modeling of $\varepsilon_{\mathrm{Nd}}$ distribution in the Mediterranean basins. Biogeosciences Discussions. http://dx.doi.org/10.5194/bg-2016-109.

Bard, E., Delaygue, G., Rostek, F., Antonioli, F., Silenzi, S., Schrag, D.P., 2002. Hydrological conditions over the western Mediterranean basin during the deposition of the cold Sapropel 6 (ca. 175 kyr BP). Earth Planet. Sci. Lett. 202, $481-494$.

Bard, E., 2013. Out of the African humid period. Science 342, 808-809.

Bar-Matthews, M., Ayalon, A., Kaufman, A., 2000. Timing and hydrological conditions of Sapropel events in the Eastern Mediterranean, as evident from speleothems, Soreq cave. Isr. Chem. Geol. 169, 145-156.

Bar-Matthews, M., Ayalon, A., Gilmour, M., Matthews, A., Hawkesworth, C.J., 2003. Sea-land oxygen isotopic relationships from planktonic foraminifera and speleothems in the Eastern Mediterranean region and their implication for paleorainfall during interglacial intervals. Geochim. Cosmochim. Acta 67, 3181-3199.

Barich, B.E., 2014. Northwest Libya from the early to late Holocene: New data on environment and subsistence from the Jebel Gharbi. Quat. Int. 320, 15-27.

Barsanti, M., Delbono, I., Schirone, A., Langone, L., Miserocchi, S., Salvi, S., Delfanti, R., 2011. Sediment reworking rates in deep sediments of the Mediterranean Sea. Sci. Total Environ. 409, 2959-2970.

Béranger, K., Mortier, L., Crepon, M., 2005. Seasonal variability of water transport through the Straits of Gibraltar, Sicily and Corsica, derived from a highresolution model of the Mediterranean circulation. Prog. Oceanogr. 66, $341-364$.

Bout-Roumazeilles, V., Combourieu-Nebout, N., Desprat, S., Siani, G., Turon, J.L. Essallami, L., 2013. Tracking atmospheric and riverine terrigenous supplies variability during the last glacial and the Holocene in central Mediterranean. Clim. Past 9, 1065-1087.

Box, M.R., Krom, M.D., Cliff, R.A., Bar-Matthews, M., Almogi-Labin, A., Ayalon, A. Paterne, M., 2011. Response of the Nile and its catchment to millennial-scale climatic change since the LGM from Sr isotopes and major elements of East Mediterranean sediments. Quat. Sci. Rev. 30, 431-442.

Castañeda, I.S., Schouten, S., Patzold, J., Lucassen, F., Kasemann, S., Kuhlmann, H., Schefuss, E., 2016. Hydroclimate variability in the Nile River Basin during the past 28,000 years. Earth Planet. Sci. Lett. 438, 47-56.

Chamley, H., 1989. Clay Sedimentology. Springer, Berlin, p. 623.

Coulthard, T.J., Ramirez, J.A., Barton, N., Rogerson, M., Brücher, T., 2013. Were rivers flowing across the Sahara during the last Interglacial? implications for human 
migration through Africa. Plos One 8, e74834. http://dx.doi.org/10.1371/ journal.pone.0074834.

De Lange, G.J., Middelburg, J.J., Pruysers, P.A., 1989. Middle and Late Quaternary depositional sequences and cycles in the eastern Mediterranean - discussion. Sedimentology 36, 151-156.

De Lange, G.J., Thomson, J., Reitz, A., Slomp, C.P., Principato, M.S., Erba, E., Corselli, C., 2008. Synchronous basin-wide formation and redox-controlled preservation of a Mediterranean sapropel. Nat. Geosci. 1, 606-610.

Dolenec, T., Faganeli, J., Pirc, S., 1998. Major, minor and trace elements in surficial sediments from the open Adriatic Sea: a regional geochemical study. Geol. Croat. 51, 59-73.

Drake, N.A., Blench, R.M., Armitage, S.J., Bristow, C.S., White, K.H., 2011. Ancient watercourses and biogeography of the Sahara explain the peopling of the desert. Proc. Natl. Acad. Sci. U. S. A. 108, 458-462.

Ehrmann, W., Schmiedl, G., Hamann, Y., Kuhnt, T., 2007a. Distribution of clay minerals in surface sediments of the Aegean Sea: a compilation. Int. J. Earth Sci. 96, 769-780.

Ehrmann, W., Schmiedl, G., Hamann, Y., Kuhnt, T., Hemleben, C., Siebel, W., 2007b. Clay minerals in late glacial and Holocene sediments of the northern and southern Aegean Sea. Palaeogeogr. Palaeoclimatol. Palaeoecol. 249, 36-57.

Emeis, K.C., Struck, U., Schulz, H.M., Rosenberg, R., Bernasconi, S., Erlenkeuser, H., Sakamoto, T., Martinez-Ruiz, F., 2000. Temperature and salinity variations of Mediterranean Sea surface waters over the last 16,000 years from records of planktonic stable oxygen isotopes and alkenone unsaturation ratios. Palaeogeogr. Palaeoclimatol. Palaeoecol. 158, 259-280.

Emeis, K.C., Schulz, H., Struck, U., Rossignol-Strick, M., Erlenkeuser, H., Howell, M.W., Kroon, D., Mackensen, A., Ishizuka, S., Oba, T., Sakamoto, T., Koizumi, I., 2003. Eastern Mediterranean surface water temperatures and $\delta^{18} \mathrm{O}$ composition during deposition of sapropels in the late Quaternary. Paleoceanography 18, 1005. http://dx.doi.org/10.1029/2000PA000617.

Filippidi, A., Triantaphyllou, M.V., De Lange, G.J., 2016. Eastern-Mediterranean ventilation variability during sapropel S1 formation, evaluated at two sites influenced by deep-water formation from Adriatic and Aegean Seas. Quat. Sci. Rev. http://dx.doi.org/10.1016/j.quascirev.2016.05.024.

Fontugne, M., Arnold, M., Labeyrie, L., Paterne, M., Calvert, S., Duplessy, J., 1994. Paleoenvironment, sapropel chronology, and Nile river discharge during the last 20,000 years as indicated by deep-sea sediment records in the eastern Mediterranean. Radiocarbon 34, 75-88.

Foucault, A., Stanley, D.J., 1989. Late Quaternary paleoclimatic oscillations in East Africa recorded by heavy minerals in the Nile delta. Nature 339, 44-46.

Foucault, A., Mélière, F., 2000. Palaeoclimatic cyclicity in central Mediterranean Pliocene sediments: the mineralogical signal. Palaeogeogr. Palaeoclimatol. Palaeoecol. 158, 311-323.

Freydier, R., Michard, A., de Lange, G.J., Thomson, J., 2001. Nd isotopic compositions of Eastern Mediterranean sediments: tracers of the Nile influence during sapropel S1 formation? Mar. Geol. 177, 45-62.

Giraudi, C., Mercuri, A.M., Esu, D., 2013. Holocene palaeoclimate in the northern Sahara margin (Jefara Plain, northwestern Libya). Holocene 23, 339-352.

Goudeau, M.L.S., Grauel, A.L., Bernasconi, S.M., de Lange, G.J., 2013. Provenance of surface sediments along the southeastern Adriatic coast off Italy: an overview. Estuar. Coast. Shelf Sci. 134, 45-56.

Goudeau, M.L.S., Grauel, A.L., Tessarolo, C., Leider, A., Chen, L., Bernasconi, S.M., Versteegh, G.J.M., Zonneveld, K.A.F., Boer, W., Alonso-Hernandez, C.M., de Lange, G.J., 2014. The glacial-interglacial transition and Holocene environmental changes in sediments from the Gulf of Taranto, central Mediterranean. Mar. Geol. 348, 88-102.

Goudeau, M.L.S., Reichart, G.J., Wit, J.C., de Nooijer, L.J., Grauel, A.L., Bernasconi, S.M., de Lange, G.J., 2015. Seasonality variations in the Central Mediterranean during climate change events in the Late Holocene. Palaeogeogr. Palaeoclimatol. Palaeoecol. 418, 304-318.

Goudie, A.S., Middleton, N.J., 2001. Saharan dust storms: nature and consequences. Earth Sci. Rev. 56, 179-204.

Grimm, R., Maier-Reimer, E., Mikolajewicz, U., Schmiedl, G., Muller-Navarra, K., Adloff, F., Grant, K.M., Ziegler, M., Lourens, L.J., Emeis, K.C., 2015. Late glacial initiation of Holocene eastern Mediterranean sapropel formation. Nat. Commun. 6, 7099. http://dx.doi.org/10.1038/ncomms8099.

Grousset, F.E., Rognon, P., Coudegaussen, G., Pedemay, P., 1992. Origins of periSaharan dust deposits traced by their Nd and Sr isotopic composition. Palaeogeogr. Palaeoclimatol. Palaeoecol. 93, 203-212.

Grousset, F.E., Parra, M., Bory, A., Martinez, P., Bertrand, P., Shimmield, G., Ellam, R.M., 1998. Saharan wind regimes traced by the Sr-Nd isotopic composition of subtropical Atlantic sediments: Last Glacial maximum vs. today. Quat. Sci. Rev. 17, 395-409.

Grousset, F.E., Biscaye, P.E., 2005. Tracing dust sources and transport patterns using $\mathrm{Sr}, \mathrm{Nd}$ and Pb isotopes. Chem. Geol. 222, 149-167.

Guerzoni, S., Molinaroli, E., Chester, R., 1997. Saharan dust inputs to the western Mediterranean Sea: depositional patterns, geochemistry and sedimentological implications. Deep Sea Res. Part II-Topical Stud. Oceanogr. 44, 631-654.

Güleç, N., 1991. Crust-mantle interaction in Western Turkey: implications from Sr and Nd isotope geochemistry of Tertiary and Quaternary volcanics. Geol. Mag. 128, 417-435.

Hamann, Y., Ehrmann, W., Schmiedl, G., Kuhnt, T., 2009. Modern and late Quaternary clay mineral distribution in the area of the SE Mediterranean Sea. Quat. Res. 71, 453-464.

Hennekam, R., Jilbert, T., Schnetger, B., de Lange, G.J., 2014. Solar forcing of Nile discharge and sapropel S1 formation in the early to middle Holocene eastern Mediterranean. Paleoceanography 29, 343-356.

Hennekam, R., Donders, T., Zwiep, K., de Lange, G., 2015. Integral view of Holocene precipitation and vegetation changes in the Nile catchment area as inferred from its delta sediments. Quat. Sci. Rev. 130, 189-199.

Hilgen, F.J., 1991. Astronomical calibration of Gauss to Matuyama sapropels in the Mediterranean and implication for the geomagnetic polarity time scale. Earth Planet. Sci. Lett. 104, 226-244.

Israelevich, P., Ganor, E., Alpert, P., Kishcha, P., Stupp, A., 2012. Predominant transport paths of Saharan dust over the Mediterranean Sea to Europe. J. Geophys. Res. Atmos. 117, D02205. http://dx.doi.org/10.1029/2011JD016482.

Jacobsen, S.B., Wasserburg, G.J., 1980. Sm-Nd isotopic evolution of chondrites. Earth Planet. Sci. Lett. 50, 139-155.

Jilbert, T., Reichart, G.J., Aeschlimann, B., Gunther, D., Boer, W., de Lange, G.J., 2010. Climate-controlled multidecadal variability in North African dust transport to the Mediterranean. Geology 38, 19-22.

Kallel, N., Paterne, M., Duplessy, J.C., VergnaudGrazzini, C., Pujol, C., Labeyrie, L., Arnold, M., Fontugne, M., Pierre, C., 1997. Enhanced rainfall in the Mediterranean region during the last sapropel event. Oceanol. Acta 20, 697-712.

Karageorgis, A., Anagnostou, C., Sioulas, A., Chronis, G., Papathanassiou, E., 1998 Sediment geochemistry and mineralogy in Milos bay, SW Kyklades, Aegean Sea, Greece. J. Mar. Syst. 16, 269-281.

Klaver, M., Djuly, T., de Graaf, S., Sakes, A., Wijbrans, J., Davies, G., Vroon, P., 2015. Temporal and spatial variations in provenance of Eastern Mediterranean Sea sediments: implications for Aegean and Aeolian arc volcanism. Geochim. Cosmochim. Acta 153, 149-168.

Kotthoff, U., Pross, J., Muller, U.C., Peyron, O., Schmiedl, G., Schulz, H., Bordon, A., 2008. Climate dynamics in the borderlands of the Aegean Sea during formation of sapropel S1 deduced from a marine pollen record. Quat. Sci. Rev. 27 $832-845$.

Krom, M.D., Cliff, R.A., Eijsink, L.M., Herut, B., Chester, R., 1999a. The characterisation of Saharan dusts and Nile particulate matter in surface sediments from the Levantine basin using Sr isotopes. Mar. Geol. 155, 319-330.

Krom, M.D., Michard, A., Cliff, R.A., Strohle, K., 1999b. Sources of sediment to the Ionian Sea and western Levantine basin of the Eastern Mediterranean during S1 sapropel times. Mar. Geol. 160, 45-61.

Larrasoaña, J.C., Roberts, A.P., Rohling, E.J., Winklhofer, M., Wehausen, R., 2003. Three million years of monsoon variability over the northern Sahara. Clim. Dyn. 21, 689-698.

Larrasoaña, J.C., Roberts, A.P., Rohling, E.J., 2013. Dynamics of green Sahara periods and their role in hominin evolution. Plos One 8, e76514. http://dx.doi.org/ 10.1371/journal.pone.0076514.

Lézine, A.M., Hely, C., Grenier, C., Braconnot, P., Krinner, G., 2011. Sahara and Sahel vulnerability to climate changes, lessons from Holocene hydrological data. Quat. Sci. Rev. 30, 3001-3012.

Lolis, C.J., Bartzokas, A., Katsoulis, B.D., 2002. Spatial and temporal 850 hPA air temperature and sea-surface temperature covariances in the Mediterranean region and their connection to atmospheric circulation. Int. J. Climatol. 22, 663-676.

Lourens, L.J., Wehausen, R., Brumsack, H.J., 2001. Geological constraints on tidal dissipation and dynamical ellipticity of the Earth over the past three million years. Nature 409, 1029-1033.

Magny, M., Vanniere, B., Calo, C., Millet, L., Leroux, A., Peyron, O., Zanchetta, G., La Mantia, T., Tinner, W., 2011. Holocene hydrological changes in south-western Mediterranean as recorded by lake-level fluctuations at Lago Preola, a coastal lake in southern Sicily, Italy. Quat. Sci. Rev. 30, 2459-2475.

Magny, M., Combourieu-Nebout, N., de Beaulieu, J.L., Bout-Roumazeilles, V., Colombaroli, D., Desprat, S., Francke, A., Joannin, S., Ortu, E., Peyron, O., Revel, M., Sadori, L., Siani, G., Sicre, M.A., Samartin, S., Simonneau, A., Tinner, W., Vanniere, B., Wagner, B., Zanchetta, G., Anselmetti, F., Brugiapaglia, E., Chapron, E., Debret, M., Desmet, M., Didier, J., Essallami, L., Galop, D., Gilli, A., Haas, J.N., Kallel, N., Millet, L., Stock, A., Turon, J.L., Wirth, S., 2013. North-south palaeohydrological contrasts in the central Mediterranean during the Holocene: tentative synthesis and working hypotheses. Clim. Past 9, 2043-2071.

Mandel, R.D., Simmons, A.H., 2001. Prehistoric occupation of late quaternary landscapes near Kharga Oasis, Western Desert of Egypt. Geoarchaeol. Int. J. 16, 95-117.

Manning, K., Timpson, A., 2014. The demographic response to Holocene climate change in the Sahara. Quat. Sci. Rev. 101, 28-35.

Martinez-Ruiz, F., Kastner, M., Gallego-Torres, D., Rodrigo-Gamiz, M., NietoMoreno, V., Ortega-Huertas, M., 2015. Paleoclimate and paleoceanography over the past 20,000 yr in the Mediterranean Sea Basins as indicated by sediment elemental proxies. Quat. Sci. Rev. 107, 25-46.

Mercone, D., Thomson, J., Croudace, I.W., Siani, G., Paterne, M., Troelstra, S., 2000. Duration of S1, the most recent sapropel in the eastern Mediterranean Sea, as indicated by accelerator mass spectrometry radiocarbon and geochemical evidence. Paleoceanography 15, 336-347.

Milner, A.M., Collier, R.E.L., Roucoux, K.H., Muller, U.C., Pross, J., Kalaitzidis, S., Christanis, K., Tzedakis, P.C., 2012. Enhanced seasonality of precipitation in the Mediterranean during the early part of the Last Interglacial. Geology 40, 919-922.

Moreno, T., Querol, X., Castillo, S., Alastuey, A., Cuevas, E., Herrmann, L., Mounkaila, M., Elvira, J., Gibbons, W., 2006. Geochemical variations in aeolian mineral particles from the Sahara-Sahel Dust Corridor. Chemosphere 65, $261-270$. 
Nijenhuis, I.A., de Lange, G.J., 2000. Geochemical constraints on Pliocene sapropel formation in the eastern Mediterranean. Mar. Geol. 163, 41-63.

Osborne, A.H., Vance, D., Rohling, E.J., Barton, N., Rogerson, M., Fello, N., 2008 A humid corridor across the Sahara for the migration of early modern human out of Africa 120,000 years ago. Proc. Natl. Acad. Sci. U. S. A. 105, 16444-16447.

Osborne, A.H., Marino, G., Vance, D., Rohling, E.J., 2010. Eastern Mediterranean surface water Nd during Eemian sapropel S5: monitoring northerly (mid-latitude) versus southerly (sub-tropical) freshwater contributions. Quat. Sci. Rev. 29, 2473-2483.

Padoan, M., Garzanti, E., Harlavan, Y., Villa, I.M., 2011. Tracing Nile sediment sources by $\mathrm{Sr}$ and Nd isotope signatures (Uganda, Ethiopia, Sudan). Geochim. Cosmochim. Acta 75, 3627-3644.

Paillou, P., Schuster, M., Tooth, S., Farr, T., Rosenqvist, A., Lopez, S., Malezieux, J.M., 2009. Mapping of a major paleodrainage system in eastern Libya using orbital imaging radar: the Kufrah River. Earth Planet. Sci. Lett. 277, 327-333.

Paillou, P., Tooth, S., Lopez, S., 2012. The Kufrah paleodrainage system in Libya: a past connection to the Mediterranean Sea? Comptes Rendus Geosci. 344 406-414.

Peyron, O., Goring, S., Dormoy, I., Kotthoff, U., Pross, J., de Beaulieu, J.L., DrescherSchneider, R., Vanniere, B., Magny, M., 2011. Holocene seasonality changes in the central Mediterranean region reconstructed from the pollen sequences of Lake Accesa (Italy) and Tenaghi Philippon (Greece). Holocene 21, 131-146.

Peyron, O., Magny, M., Goring, S., Joannin, S., de Beaulieu, J.L., Brugiapaglia, E., Sadori, L., Garfi, G., Kouli, K., Ioakim, C., Combourieu-Nebout, N., 2013. Contrasting patterns of climatic changes during the Holocene across the Italian Peninsula reconstructed from pollen data. Clim. Past 9, 1233-1252.

Pinardi, N., Masetti, E. 2000. Variability of the large scale general circulation of the Mediterranean Sea from observations and modelling: a review. Palaeogeogr. Palaeoclimatol. Palaeoecol. 158, 153-174.

Pinardi, N., Zavatarelli, M., Adani, M., Coppini, G., Fratianni, C., Oddo, P. Simoncelli, S., Tonani, M., Lyubartsev, V., Dobricic, S., Bonaduce, A., 2015. Mediterranean Sea large-scale low-frequency ocean variability and water mass formation rates from 1987 to 2007: a retrospective analysis. Prog. Oceanogr 132, 318-332.

Reimer, P.J., Bard, E., Bayliss, A., Beck, J.W., Blackwell, P.G., Ramsey, C.B., Buck, C.E. Cheng, H., Edwards, R.L., Friedrich, M., Grootes, P.M., Guilderson, T.P. Haflidason, H., Hajdas, I., Hatte, C., Heaton, T.J., Hoffmann, D.L., Hogg, A.G., Hughen, K.A., Kaiser, K.F., Kromer, B., Manning, S.W., Niu, M., Reimer, R.W., Richards, D.A., Scott, E.M., Southon, J.R., Staff, R.A., Turney, C.S.M., van der Plicht, J., 2013. Intcal13 and Marine13 radiocarbon age calibration curves, 0-50,000 years cal BP. Radiocarbon 55, 1869-1887.

Reitz, A., de Lange, G.J., 2006. Abundant Sr-rich aragonite in eastern Mediterranean sapropel S1: diagenetic vs. detrital/biogenic origin. Palaeogeogr. Palaeoclimatol. Palaeoecol. 235, 135-148.

Reitz, A., Thomson, J., de Lange, G.J., Hensen, C., 2006. Source and development of large manganese enrichments above eastern Mediterranean sapropel S1. Paleoceanography 21, PA3007. http://dx.doi.org/10.1029/2005PA001169.

Revel, M. Ducassou, F. Grousset, F.E., Bernasconi, S.M., Migeon, S., Revillon, S. Mascle, J., Murat, A., Zaragosi, S., Bosch, D., 2010. 100,000 Years of African monsoon variability recorded in sediments of the Nile margin. Quat. Sci. Rev. 29, 1342-1362.

Revel, M., Ducassou, E., Skonieczny, C., Colin, C., Bastian, L., Bosch, D., Migeon, S., Mascle, J., 2015. 20,000 years of Nile River dynamics and environmental changes in the Nile catchment area as inferred from Nile upper continenta slope sediments. Quat. Sci. Rev. 130, 200-221.

Rodrigo-Gámiz, M., Martinez-Ruiz, F., Chiaradia, M., Jimenez-Espejo, F.J., Ariztegui, D., 2015. Radiogenic isotopes for deciphering terrigenous input provenance in the western Mediterranean. Chem. Geol. 410, 237-250.

Roether, W., Manca, B.B., Klein, B., Bregant, D., Georgopoulos, D., Beitzel, V. Kovacevic, V., Luchetta, A., 1996. Recent changes in eastern Mediterranean deep waters. Science 271, 333-335.

Rohling, E.J., Hilgen, F.J., 1991. The eastern Mediterranean climate at times of sapropel formation: a review. Geol. En. Mijnb. 70, 253-264.

Rohling, E.J., 1994. Review and new aspects concerning the formation of Eastern Mediterranean sapropels. Mar. Geol. 122, 1-28.

Rohling, E.J., Cane, T.R., Cooke, S., Sprovieri, M., Bouloubassi, I., Emeis, K.C., Schiebel, R., Kroon, D., Jorissen, F.J., Lorre, A., Kemp, A.E.S., 2002. African monsoon variability during the previous interglacial maximum. Earth Planet. Sci. Lett. 202, 61-75.

Rohling, E.J., Sprovieri, M., Cane, T., Casford, J.S.L., Cooke, S., Bouloubassi, I., Emeis, K.C., Schiebel, R., Rogerson, M., Hayes, A., Jorissen, F.J., Kroon, D., 2004. Reconstructing past planktic foraminiferal habitats using stable isotope data: a case history for Mediterranean sapropel S5. Mar. Micropaleontol. 50, 89-123.

Rohling, E.J., Pälike, H., 2005. Centennial-scale climate cooling with a sudden cold event around 8,200 years ago. Nature 434, 975-979.

Rohling, E.J., Marino, G., Grant, K.M., 2015. Mediterranean climate and oceanography, and the periodic development of anoxic events (sapropels). Earth Sci. Rev. 143, 62-97.

Rossignol-Strick, M., Nesteroff, W., Olive, P., Vergnaudgrazzini, C., 1982. After the deluge: Mediterranean stagnation and sapropel formation. Nature 295, 105-110.

Rossignol-Strick, M., 1987. Rainy periods and bottom water stagnation initiating brine accumulation and metal concentrations: 1. the Late Quaternary. Paleoceanography 2, 333-360.

Rutten, A., de Lange, G.J., 2002. A novel selective extraction of barite, and its application to eastern Mediterranean sediments. Earth Planet. Sci. Lett. 198, $11-24$.

Rutten, A., de Lange, G.J., Ziveri, P., Thomson, J., van Santvoort, P.J.M., Colley, S., Corselli, C., 2000. Recent terrestrial and carbonate fluxes in the pelagic eastern Mediterranean: a comparison between sediment trap and surface sediment. Palaeogeogr. Palaeoclimatol. Palaeoecol. 158, 197-213.

Scheuvens, D., Schutz, L., Kandler, K., Ebert, M., Weinbruch, S., 2013. Bulk composition of northern African dust and its source sediments-a compilation. Earth Sci. Rev. 116, 170-194.

Scrivner, A.E., Vance, D., Rohling, E.J., 2004. New neodymium isotope data quantify Nile involvement in Mediterranean anoxic episodes. Geology 32, 565-568.

Siani, G., Paterne, M., Arnold, M., Bard, E., Metivier, B., Tisnerat, N., Bassinot, F., 2000. Radiocarbon reservoir ages in the Mediterranean Sea and Black Sea. Radiocarbon 42, 271-280.

Slomp, C.P., Thomson, J., de Lange, G.J., 2004. Controls on phosphorus regeneration and burial during formation of eastern Mediterranean sapropels. Mar. Geol. 203, 141-159.

Sperling, M., Schmiedl, G., Hemleben, C., Emeis, K.C., Erlenkeuser, H., Grootes, P.M., 2003. Black Sea impact on the formation of eastern Mediterranean sapropel S1? Evidence from the Marmara Sea. Palaeogeogr. Palaeoclimatol. Palaeoecol. 190, $9-21$.

Spötl, C., Nicolussi, K., Patzelt, G., Boch, R., Team, D., 2010. Humid climate during deposition of sapropel 1 in the Mediterranean Sea: assessing the influence on the Alps. Glob. Planet. Change 71, 242-248.

Stuiver, M., Reimer, P.J., Reimer, R., 2005. Calib5.0.

Stuut, J.B., Smalley, I., O'Hara-Dhand, K., 2009. Aeolian dust in Europe: African sources and European deposits. Quat. Int. 198, 234-245.

Tachikawa, K., Roy-Barman, M., Michard, A., Thouron, D., Yeghicheyan, D., Jeandel, C., 2004. Neodymium isotopes in the Mediterranean Sea: comparison between seawater and sediment signals. Geochimica Cosmochimica Acta 68, 3095-3106.

Tachikawa, K., Piotrowski, A., Bayon, G., 2014. Neodymium associated with foraminiferal carbonate as a recorder of seawater isotopic signatures. Quat. Sci. Rev. 88, 1-13.

Tachikawa, K., Vidal, L., Cornuault, M., Garcia, M., Pothin, A., Sonzogni, C., Bard, E., Menot, G., Revel, M., 2015. Eastern Mediterranean Sea circulation inferred from the conditions of S1 sapropel deposition. Clim. Past 11, 855-867.

Tanaka, T., Togashi, S., Kamioka, H., Amakawa, H., Kagami, H., Hamamoto, T., Yuhara, M., Orihashi, Y., Yoneda, S., Shimizu, H., Kunimaru, T., Takahashi, K., Yanagi, T., Nakano, T., Fujimaki, H., Shinjo, R., Asahara, Y., Tanimizu, M., Dragusanu, C., 2000. JNdi-1: a neodymium isotopic reference in consistency with LaJolla neodymium. Chem. Geol. 168, 279-281.

Thirlwall, M.F., 1991. Long-term reproducibility of multicollector $\mathrm{Sr}$ and $\mathrm{Nd}$ isotope analysis. Chem. Geol. 94, 85-104.

Toucanne, S., Mintoo, C.M.A., Fontanier, C., Bassetti, M.A., Jorry, S.J., Jouet, G., 2015. Tracking rainfall in the northern Mediterranean borderlands during sapropel deposition. Quat. Sci. Rev. 129, 178-195.

Tuenter, E., Weber, S.L., Hilgen, F.J., Lourens, L.J., 2003. The response of the African summer monsoon to remote and local forcing due to precession and obliquity. Glob. Planet. Change 36, 219-235.

Tzedakis, P.C., 2007. Seven ambiguities in the Mediterranean palaeoenvironmental narrative. Quat. Sci. Rev. 26, 2042-2066.

Van der Weijden, C.H., 2002. Pitfalls of normalization of marine geochemical data using a common divisor. Mar. Geol. 184, 167-187.

Van Dijk, D., Houba, V.J.G., 2000. Homogeneity and stability of materials distributed within the wageningen evaluating programmes for analytical laboratories. Commun. Soil Sci. Plant Anal. 31, 1745-1756.

Van Helmond, N., Hennekam, R., Donders, T., Bunnik, F., De Lange, G., Brinkhuis, H. Sangiorgi, F., 2015. Marine productivity leads organic matter preservation in sapropel S1: palynological evidence from a core east of the Nile River outflow. Quat. Sci. Rev. 108, 130-138.

Van Santvoort, P.J.M., de Lange, G.J., Thomson, J., Cussen, H., Wilson, T.R.S., Krom, M.D., Strohle, K., 1996. Active post-depositional oxidation of the most recent sapropel (S1) in sediments of the eastern Mediterranean Sea. Geochim. Cosmochim. Acta 60, 4007-4024.

Venkatarathnam, K. Ryan, W.B.F. 1971. Dispersal patterns of clay minerals in sediments of the eastern Mediterranean Sea. Mar. Geol. 11, 261-282.

Wehausen, R., Brumsack, H.J., 1999. Cyclic variations in the chemical composition of eastern Mediterranean Pliocene sediments: a key for understanding sapropel formation. Mar. Geol. 153, 161-176.

Wehausen, R., Brumsack, H.J., 2000. Chemical cycles in Pliocene sapropel-bearing and sapropel-barren eastern Mediterranean sediments. Palaeogeogr Palaeoclimatol. Palaeoecol. 158, 325-352.

Weldeab, S., Emeis, K.C., Hemleben, C., Siebel, W., 2002a. Provenance of lithogenic surface sediments and pathways of riverine suspended matter in the Eastern Mediterranean Sea: evidence from ${ }^{143} \mathrm{Nd} /{ }^{144} \mathrm{Nd}$ and ${ }^{87} \mathrm{Sr} /{ }^{86} \mathrm{Sr}$ ratios. Chem. Geol. 186, 139-149.

Weldeab, S., Emeis, K.C., Hemleben, C., Vennemann, T.W., Schulz, H., 2002b. Sr and Nd isotope composition of Late Pleistocene sapropels and nonsapropelic sediments from the Eastern Mediterranean Sea: implications for detrital influx and climatic conditions in the source areas. Geochim. Cosmochim. Acta 66, 3585-3598.

Williams, M.A.J., Adamson, D., Cock, B., McEvedy, R., 2000. Late Quaternary environments in the White Nile region. Sudan. Glob. Planet. Change 26, 305-316.

Wu, J., Liu, Z., Zhou, C., 2012. Late quaternary glacial cycle and precessional period of 
clay mineral assemblages in the western pacific warm pool. Chin. Sci. Bull. 57, 3748-3760.

Wu, J., Liu, Z., Zhou, C., 2013. Provenance and supply of Fe-enriched terrigenous sediments in the western equatorial Pacific and their relation to precipitation variations during the late Quaternary. Glob. Planet. Change 108, 56-71.

Zanchetta, G., Drysdale, R.N., Hellstrom, J.C., Fallick, A.E., Isola, I., Gagan, M.K. Pareschi, M.T., 2007. Enhanced rainfall in the Western Mediterranean during deposition of sapropel S1: stalagmite evidence from Corchia cave (Central Italy). Quat. Sci. Rev. 26, 279-286.

Zhao, Y.L., Colin, C., Liu, Z.F., Paterne, M., Siani, G., Xie, X., 2012. Reconstructing precipitation changes in northeastern Africa during the Quaternary by clay mineralogical and geochemical investigations of Nile deep-sea fan sediments.
Quat. Sci. Rev. 57, 58-70.

Zhao, Y.L., Colin, C., Liu, Z.F. Bonneau, L., Siani, G., 2016. Climate forcing of terrigenous sediment input to the central Mediterranean Sea since the early Pleistocene. Palaeogeogr. Palaeoclimatol. Palaeoecol. 442, 23-35.

Zhornyak, L.V., Zanchetta, G., Drysdale, R.N., Hellstrom, J.C., Isola, I., Regattieri, E, Piccini, L., Baneschi, I., Couchoud, I., 2011. Stratigraphic evidence for a "pluvial phase" between ca 8200-7100 ka from Renella cave (Central Italy). Quat. Sci. Rev. 30, 409-417.

Zielhofer, C., Faust, D., Linstadter, J., 2008. Late Pleistocene and Holocene alluvial archives in the Southwestern Mediterranean: changes in fluvial dynamics and past human response. Quat. Int. 181, 39-54. 